\title{
Palaeoenvironmental significance of Late Permian palaeosols in the South-Eastern Iberian Ranges, Spain
}

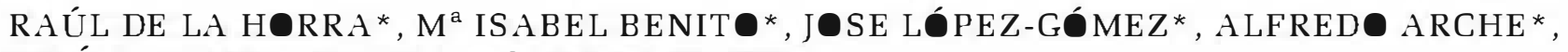 \\ JOSÉ F. BARRENECHEA † and JA VIER LUQUE $\dagger$

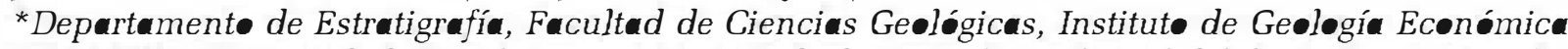 \\ UCM-CSIC, Universidad Complutense, 28040 Madrid, Spain (E-mail: rul.delahørr@ge•ucm.es)

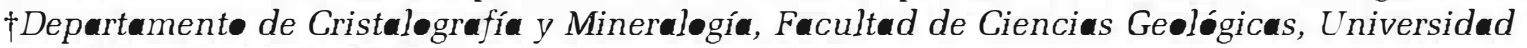 \\ Complutense, 28040 Madrid, Spain
}

\begin{abstract}
The Late Permian (Wuchiapingian) Alcotas Formation in the SE Iberian Ranges consists of one red alluvial succession where abundant soil profiles developed. Detailed petrographical and sedimentological studies in seven sections of the Alcotas Formation allow six different types of palaeosols, with distinctive characteristics and different palaeogeographical distribution, to be distinguished throughout the South-eastern Iberian Basin. These characteristics are, in turn, related to topographic, climatic and tectonic controls. The vertical distribution of the palaeosols is used to differentiate the formation in three parts from bottom to top showing both drastic and gradual vertical upwards palaeoenvironmental changes in the sections. Reconstruction of palaeoenvironmental conditions based on palaeosols provides evidence for understanding the events that occurred during the Late Permian, some few millions of years before the well-known Permian-Triassic global crisis.
\end{abstract}

Keywords Biotic crisis, Iberian Ranges, Late Permian, palaeosols, PermianTriassic boundary.

\section{INTRODUCTION}

The large amount of recent papers (Yin \& Tong, 1998; Retallack \& Krull, 1999; Twitchett et al., 2001; Benton, 2003; Fluteau et al., 2001; Racki, 2003; Kiehl \& Shields, 2005; Twitchett, 2006; among many others) on the Late Permian and Permian-Triassic boundary biotic crisis demonstrates the renewed interest in this subject. However, in most Western European basins, the sedimentary hiatus during the Late Permian and the lack of fossils hinder the location of the Permian-Triassic transition in continental sedimentary rocks. Nevertheless, the analysis of the stratigraphic and sedimentological data recorded in these rocks has allowed the identification of several climatic changes in the Western European domain. This information leads to improved correlations among the different basins (Schneider et al., 2006) and to a better knowledge of the Late Permian events that resulted in the end-

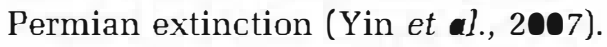

The study of palaeosols is an important tool in stratigraphic analyses, ancient landscape reconstructions or palaeoclimatic studies because the usual incompleteness of the continental sedimentary record is less problematic for palaeosols (Retallack, 1998), but also because palaeosols are located, by definition, in the place where they formed and can be considered trace fossils of ecosystems (Kraus, 1999; Retallack, 2001). For example, certain changes in the evolution of palaeosols have demonstrated landscape ecological shifts at the Permian-Triassic boundary in huge areas of Antarctica and the basins of Sydney and Bowen in Australia (Retallack, 1999). 
Some of these changes have also been observed in adjacent areas of the Gondwanan backarc basin (Retallack \& Krull, 1999).

The study of palaeosols has been used recently to explain the tectonic and sedimentary evolution of some Spanish Permian and Triassic basins of the western Iberian Ranges and Minorca (AlonsoZarza et al., 1999; Gómez-Gras \& Alonso-Zarza, 2003). In the SE Iberian Ranges, palaeosols are a distinctive feature of the Late Permian Alcotas Formation and their presence has been reported before in this unit and in its lateral equivalent formations by different authors (Ramos, 1979; López-Gómez, 1985; Pérez-Arlucea, 1985). However, there are no previous studies on the identification and classification of the different pedogenic levels developed in the Late Permian of the Iberian Ranges. In addition, there are no studies relating palaeosols with the Late Permian general sedimentary, palaeoenvironmental and biotic changes.

The Permian geological record of the Iberian Basin has been studied in detail during the last three decades (see the synthesis of Sopeña et al., 1988; López-Gómez et al., 2002; Sopeña \& Sánchez-Moya, 2004). These tectonic, sedimentological and palaeontological data have recently allowed subdivision of the Alcotas Formation (Upper Permian) into Lower, Middle and Upper parts (Benito et al., 2005; López-Gómez et al., 2005a). The boundaries between these three parts are related to important palaeoenvironmental and palaeogeographical changes. The aim of this work was to show how the characteristics of the palaeosols studied within the different parts of the Alcotas Formation provide valuable data to reconstruct the palaeoenvironment of the SE Iberian Ranges and to unravel the main controls operating in the sedimentary record of these rocks during the Late Permian.

\section{GEOLOGICAL AND STRATIGRAPHICAL SETTING}

The Iberian Ranges are a linear structure trending NW-SE in the north-east edge of the Iberian microplate (Fig. 1). This structure started to develop as a rift basin during the Early Permian and experienced several extensional periods during the Late Permian, Mesozoic and Cenozoic. Folding and thrusting associated with two compressive events in the Cenozoic created the present-day Iberian Ranges (Sopeña et al., 1988; Salas \& Casas, 1993; Arche \& López-Gómez, 1996; López-Gómez et al., 2002). The origin of the Iberian Basin is linked to the opening of different rift basin lineaments in Western Europe during the rupture of Pangea in the Early Permian. Different highs subdivided the Iberian Basin and

A

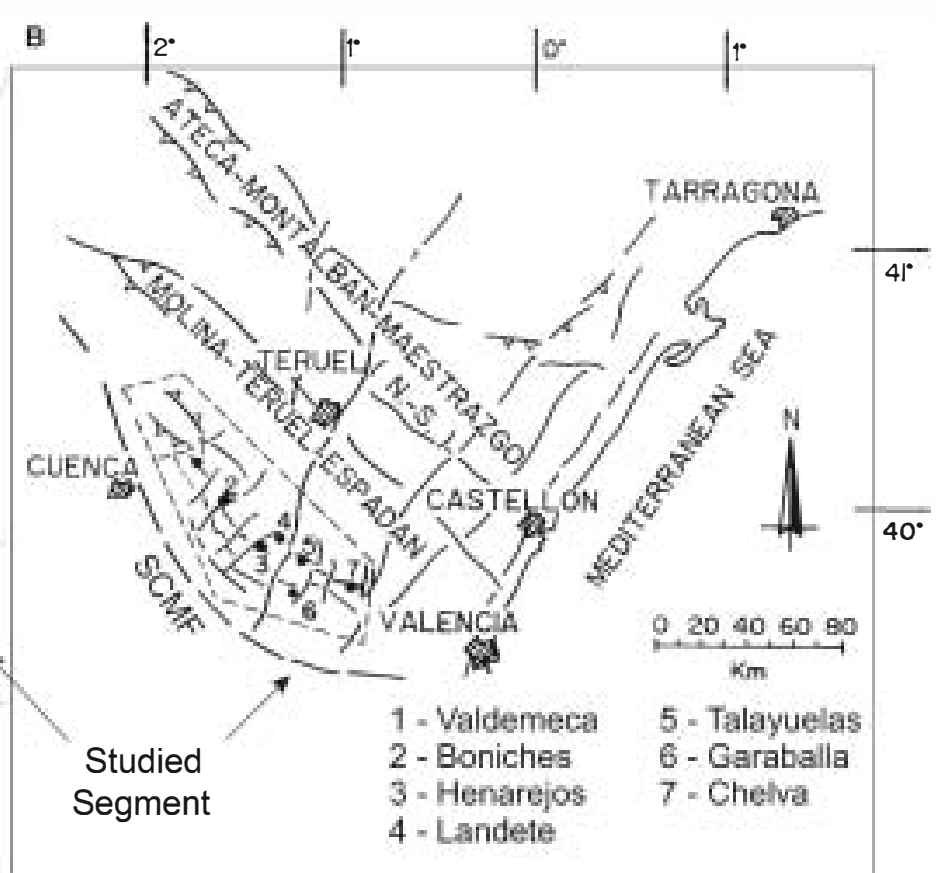

Fig. 1. (A) Palaeotectonic sketch of the Iberian Basin during the Late Permian-Early Triassic (modified from LópezGómez \& Arche, 1993). (B) Present-day geographical location of the studied area with superimposed main faults and localities. SCMF, Serranía de Cuenca Master Fault. 
conditioned its development and sedimentary filling. Upper Permian sedimentation in the Iberian Ranges is of alluvial origin and has been extensively described on the basis of its sedimentological, mineralogical and tectonic evolution (Ramos et al., 1986; Sopeña et al., 1988; LópezGómez \& Arche, 1993; Arche \& López-Gómez, 1996, 2005; Alonso-Azcárate et al., 1997; Benito et al., 2005).

The present-day configuration of the Iberian Ranges can be described as two Alpine Palaeozoic-Mesozoic chains separated by a Cenozoic basin, the so-called Aragonese and Castilian branches, to the north and south, respectively. The study area is located towards the SE of the Iberian Ranges, in the Castilian Branch, and includes the localities of Valdemeca, Boniches, Landete, Henarejos, Talayuelas, Garaballa and Chelva (Fig. 1).

The studied sections are well-exposed in the vicinity of the cited localities, where most of the Upper Permian strata crops out in the nucleus of anticlines with NW-SE-oriented main axes. These rocks do not show significant deformation because Cenozoic compressive events that caused folding of the chain were not intense enough in this area. However, important faults separate the anticlines and also cut some of their flanks. The NW-SE-oriented faults, parallel to the basin margins and to the axes of the anticlines, were mostly reactivated from older ones of Variscan origin, as is the case in the Serranía de Cuenca Master Fault. The NE-SW-trending faults separating anticlines are mainly transfer faults resulting from accommodation during the development of the Iberian Basin rifting stages (Arche \& LópezGómez, 1996) (Fig. 1). These latter secondary faults separate semi-connected neighbouring half-grabens that represent segments of a main NW-SE structural lineation. This article mainly focuses on one of these principal half-grabens situated between Valdemeca and Chelva (Fig. 1).

Lower Permian sedimentary rocks in the SE Iberian Ranges are only known from two small outcrops close to Boniches and Henarejos (Fig. 1B). Upper Permian strata, however, are well-exposed over large areas of most of the Iberian Ranges and they are separated clearly from the Lower Permian sedimentary record by an unconformity (Sopeña et al., 1988; LópezGómez et al., 2002, 2005b).

Upper Permian-Middle Triassic sedimentation is divided into two main pulses of rifting separated by an unconformity (Fig. 2). The first pulse is represented by two units of alluvial origin: the
Boniches Formation and the overlying Alcotas Formation (López-Gómez \& Arche, 1993; Arche \& López-Gómez, 1999). The palynofloras found in the Alcotas Formation and in its north-eastern lateral equivalent in the Iberian Ranges contain elements typical of Thuringian age (sensu Visscher, 1971) (=Zechstein), such as Lueckispørites virkkiae, Nuskøispørites dulhuntyi and Paravesicasp•ra splendens (Doubinger et al., 1990; Sopeña et al., 1995; Díez, 2000; López-Gómez et al., 2002). Thuringian is a well-known western European term defined for Upper Permian pollen assemblages, but is not a formally accepted time unit. The Thuringian correlates well with the Tatarian Stage of the Upper Permian of the Russian Platform and is comparable to Zone 29 of Gorsky et l. (2003). Considering that the sediments of the Boniches Formation present pollen assemblages from the Late Permian (Doubinger et al., 1990), the Alcotas Formation could be Wuchiapingian in age (LópezGómez et al., 2005b).

The second pulse of rifting is constituted by the Hoz del Gallo and Cañizar Formations, both also of continental origin. In the NW Iberian Ranges, the Hoz del Gallo Formation is subdivided into two parts separated by an unconformity (Fig. 2). Only the lower part of the Hoz del Gallo Formation contains Thuringian (Late Permian) microflora. As this part is also separated from the Alcotas Formation by another unconformity, a probable Changsingian age is suggested. From that Thuringian pollen assemblage, the palynological record is restricted to the upper part of the Cañizar Formation, which has been dated as Anisian (Doubinger et l., 1990). This observation implies that the Permian-Triassic Boundary in the Iberian Ranges is located between the two parts of the $\mathrm{Hoz}$ del Gallo Formation or somewhere between the upper part of the Hoz del Gallo Formation and the lower half of the Cañizar Formation.

The stratigraphical, sedimentological and mineralogical characteristics of the Alcotas Formation have been studied recently in detail (López-Gómez \& Arche, 1993; Alonso-Azcárate et al., 1997; Arche \& López-Gómez, 1999, 2005; Benito et l., 2005). The formation consists of red to dark brown mudstone and silts tone with local lenticular sandstone and conglomerate bodies; its total thickness reaches $210 \mathrm{~m}$.

Palaeosols, coal beds, palynological assemblages, macrofloras, mineralogy and sedimentary structures divide the Alcotas Formation into three parts: Lower, Middle and Upper (Arche \& LópezGómez, 2005). Recently, Benito et al. (2005) and López-Gómez et al. (2005a) have shown that this 


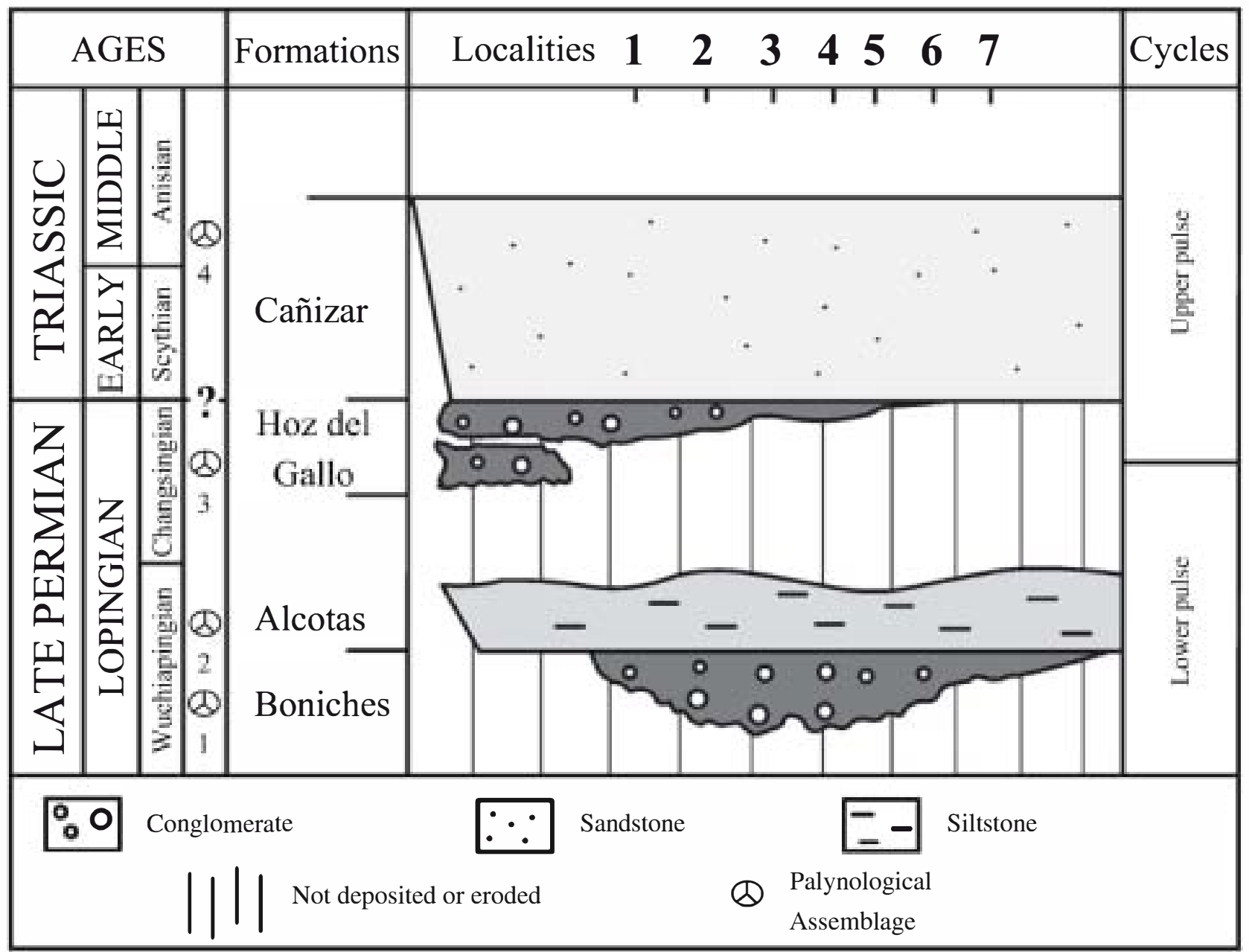

Fig. 2. Upper Permian and Lower Triassic stratigraphic succession in the studied area. Palynological assemblages 1 , 2 and 3 are of Thuringian age (Late Permian). The palynomorph association 4 is of Anisian age. Until now, there has been no description of palynoflora typical of Lower Triassic age in Iberia. See text for more details. Location of outcrops: (1) Valdemeca, (2) Boniches, (3) Henarejos, (4) Landete, (5) Talayuelas, (6) Garaballa, (7) Chelva.

three-fold division can be followed laterally throughout the studied area (Fig. 3).

The Lower Part of the formation is composed mainly of pale red mudstones and siltstones with intercalated medium to coarse-grained, 10 to $60 \mathrm{~cm}$ thick sandstones with sharp bases, current ripples and low angle planar cross-stratification. The sequence includes palaeosols, containing spherical to sub-spherical carbonate nodules, which appear continuous at the scale of the outcrop (Benito et al., 2005). This part is interpreted as a gravelly, braided fluvial system embedded in a wide, fine-grained floodplain with a high avulsion rate (Arche \& López-Gómez, 1999, 2005).

The Middle Part of the formation represents an abrupt change in lithofacies with respect to the sedimentary rocks of the Lower Part. It mainly consists of 1.3 to $2.6 \mathrm{~m}$ thick sandstones, amalgamated or separated by a red to brown, $0 \cdot 7$ to $1 \cdot 8 \mathrm{~m}$ thick, massive siltstone-mudstone. Sandstones are pale green in colour and show current ripples, lateral accretion surfaces, planar and trough cross-stratification and constitute successive fining-upward sequences. These sequences are interpreted as the migration of bars and channels in meandering and braided fluvial systems that cross wide alluvial plains (López-Gómez \& Arche, 1993; Arche \& López-Gómez, 2005). Thin coal beds and carbonaceous shales are common in the Middle Part. Abundant tree trunks and plant remains have been found along foresets and lags of the alluvial structures. In the intercalated siltstonemudstones, pollen assemblages were also recognized (Doubinger et al., 1990; Diéguez \& López-Gómez, 2005; López-Gómez et al., 2005b). A qualitative and quantitative analysis of palynomorph assemblages carried out by Diéguez \& Barron (2005) shows an important diminution of 


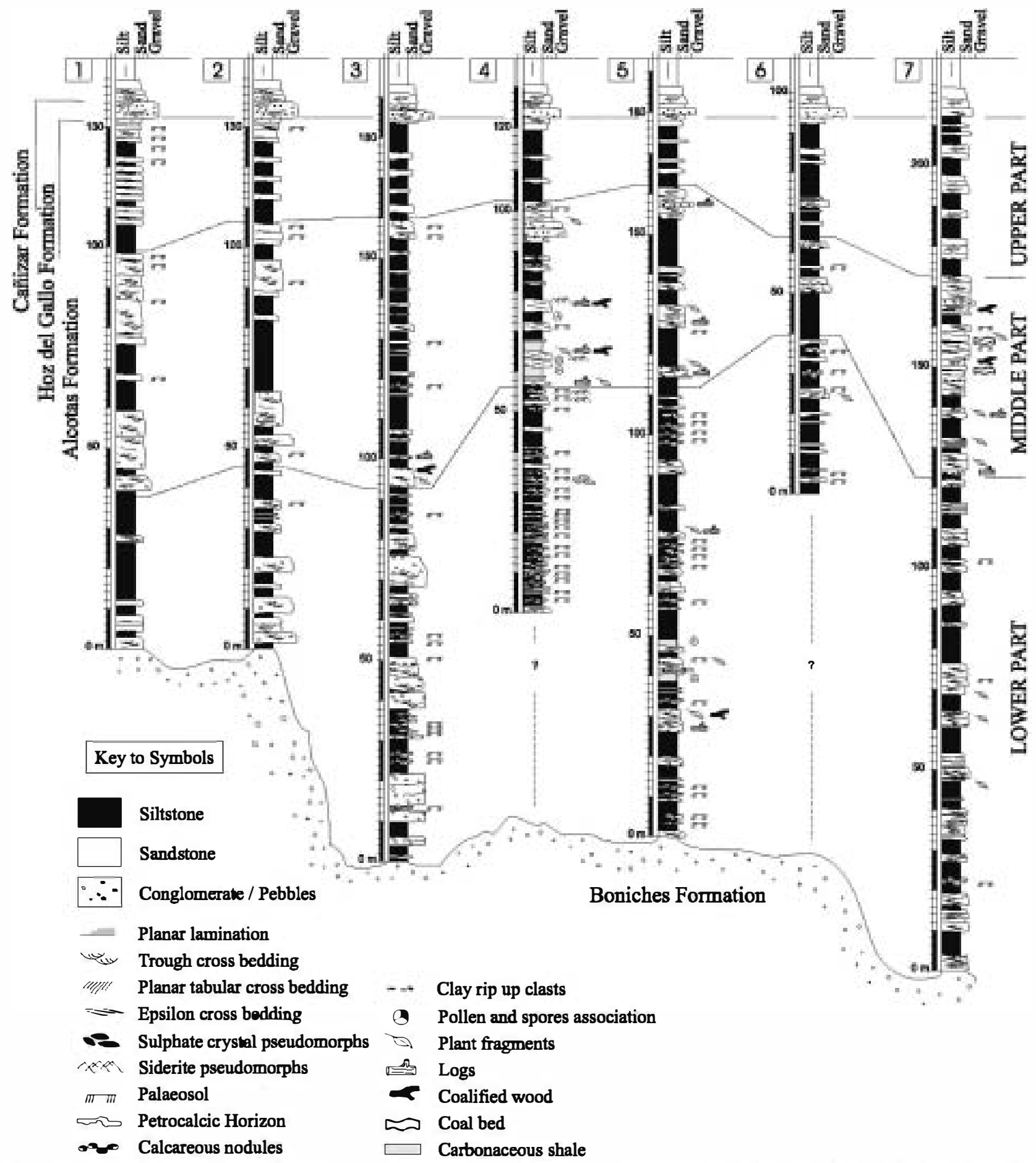

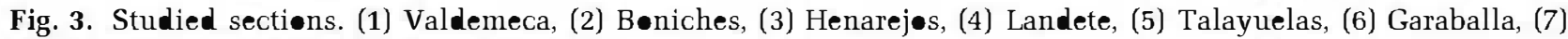
Chelva. See Figs 1 and 2 for their lecatiens.

the content and diversity of the flora. These authors interpret that, at least at the Lower Part/Middle Part transition, there was a biotic crisis prior to the Permian-Triassic Boundary.

The Upper Part of the formation shows important mineralogical and sedimentological differences. It consists of centimetre to metre-scale, fine to medium-grained, dark pink sandstones separated by pink to pale red mudstone-siltstone beds 30 to $60 \mathrm{~cm}$ thick. The top of the sandstones shows low angle planar cross-stratification and local current ripples. Sparse and isolated palaeosols with no carbonate content have been identified in this interval. The sediments of this Upper 
Part correspond to distal, very low energy, sandy, braided river systems with a high avulsion rate and marked seasonality (Arche \& López-Gómez, 2005).

\section{MATERIALS AND METHODS}

Seven selected stratigraphic sections of the Alcotas Formation were measured and sampled. Each section comprises the most representative features of the different geographical sectors of the studied area and includes detailed sedimentological and mineralogical data. A total of 160 rock samples of sandstones, siltstones and mudstones were collected. For each selected sample of sandstone and siltstone, a polished and uncovered $30 \mu \mathrm{m}$ thin section was prepared for petrographic and electron microprobe analyses. In some cases, a polished block of the sample was obtained and scanned for macroscopic description. The bulk sample mineralogy was obtained by X-ray diffraction (XRD) after grinding and homogenization of the samples to $<53 \mu \mathrm{m}$. Random-oriented powders were examined on a Siemens Kristalloflex 810 diffractometer (Siemens, Munich, Germany), using $\mathrm{Cu}-\mathrm{K} \alpha$ at $30 \mathrm{kV}$ and $40 \mathrm{~mA}$, a step size of $\bullet .03(\bullet 2 \theta)$, and time per step of $1 \mathrm{sec}$ (scan rate of $1.8^{\bullet} 20 \mathrm{~min}^{-1}$ ).

For the study of carbonates, cathodoluminescence (CL) petrography was carried out using a Technosyn $\bullet$ cold cathodoluminescent unit (Cambridge Image Technology Ltd, Cambridge, UK). After CL examination, all thin sections were stained with Alizarin Red $S$ and potassium ferricyanide (Dickson, 1966). Elemental analyses ( $\mathrm{Ca}, \mathrm{Mg}, \mathrm{Sr}, \mathrm{Mn}$ and $\mathrm{Fe}$ ) of carbonates were performed on a JEOL JXA-8900 M WD/ED electron microprobe (JE L Ltd, Tokyo, Japan). All analyses were conducted with an accelerating voltage of $15 \mathrm{kV}$ and a spot size of $5 \mu \mathrm{m}$. Detection limits were 100 p.p.m. for Mg, 250 p.p.m. for Sr, 200 p.p.m. for $\mathrm{Mn}, 250$ p.p.m. for $\mathrm{Fe}$ and 140 p.p.m. for Na.

Palaeosols of the Alcotas Formation were differentiated, carefully described, and classified into a field scheme of pedotypes using established criteria (Retallack, 1988, 1997). Each pedotype is simply a kind of palaeosol as recognized in the field (Retallack, 1994) and their features include such field characteristics as soil horizons, sharpness and lateral continuity of their boundaries, soil structure, soil colour (measured by comparison with a Munsell colour chart), presence of organism traces or fossils, size, abundance and contrast of mottles, thickness of soil with carbonate, size of nodules and parent material. Other field characteristics must be interpreted after description or even with laboratory studies. When it was possible, these features were interpreted in the field following known systems. Thus, the classification of Machette (1985) was used for the state of carbonate accumulation, the degree of development of the palaeosol was estimated using the scale of Retallack (1988) and, finally, for designation of diagnostic horizons and identification of horizons with letters (such as $\mathrm{A}, \mathrm{Bt}$ and $\mathrm{Bk}$ horizons of Table 1 and Figure 4) the USDA Soil Taxonomy system (Soil Survey Staff, 1999) was used. The different pedotypes were named after the toponymy of the study area.

Up to 144 samples and other pedofeatures such as rhyzolites, nodules or fossil specimens were obtained from selected profiles of each palaeosol. Thin sections were used for petrographic study, determination of grain-size distribution and mineral content by point-counting 500 points (Retallack, 1997) using a Swift automatic counter (James Swift and Son, Ltd, London, UK). Three classification systems have been used for the palaeosols of the Alcotas Formation: the classification by Mack et l. (1993), which is a simplified field system specifically applicable to palaeosols; and two of the well-known systems applied to modern soils: the USDA Soil Taxonomy system (Soil Survey Staff, 1999) and the Food and Agriculture Organization classification (FAO, 1998).

The optimal classification for ancient soils would be one based entirely on observable features of relatively unaltered palaeosols. In this regard, the classification system of Mack et al. (1993) could be more appropriate. However, this classification system does not include properties that may undergo changes during diagenesis. Thus, it excludes potentially useful information and severs the link between modern soils and soil environments, which is one of the main purposes of the study of palaeosols (Buurman, 1998; Kraus, 1999; Retallack, 2001). On the other hand, modern soil classification systems, such as Soil Taxonomy and FAO depend heavily on climate, nutrients and water availability, properties that are difficult to estimate in ancient soils. Palaeosols cannot be classified, therefore, with the same detail as modern soils. In the present study, palaeosols are identified on the basis of preserved properties up to order and suborder level, by comparison with modern soils, incorporating useful data for interpreting past depositional conditions, palaeoenvironments and palaeoecological changes. 


\section{Mineralogical composition of parent material}

The original sediments of the Alcotas Formation were deposited in the channels and on floodplains of braided and meandering fluvial river systems (López-Gómez, 1985; Arche \& LópezGómez, 2005). Parent materials of the palaeosols were dominantly siltstone to very fine sandstone of the overbank deposits of a wide floodplain. Banks and emergent bars of the river could become vegetated and some palaeosols also developed on top of thick sandstone beds.

The bulk mineralogy of the Alcotas Formation was obtained from samples free of observable pedogenic or diagenetic modifications. These samples basically represent unaltered parent material. The petrographic study of the sandstones shows a predominance of subarkoses, with minor presence of quartzarenites and arkoses. Quartz (65\% to $90 \%$ ) is the dominant component in the sandstone. Feldspar accounts for $6 \%$ to $34 \%$, and other important components include metamorphic rock fragments $(<6 \%)$ and detrital biotite $(<8 \%)$. The mineralogical composition of the fine-grained sediments, obtained by XRD, includes phyllosilicates, quartz, and varying proportions of feldspar and hematite. The red and purple colour of the Alcotas Formation is due mainly to this red iron oxide, which is probably not original, but the result of dehydration and recrystallization of ferric hydroxides during shallow burial (Blodgett, 1988; Retallack, 1997).

The clay mineralogy of the $<2 \mu \mathrm{m}$ and 2 to $20 \mu \mathrm{m}$ fractions was determined by Alonso-Azcárate et al. (1997) from selected samples of mudstones and siltstones. The siltstones in the transition between Boniches Formation and Alcotas Formation consist of kaolinite and illite. Illite, mainly detrital with a small proportion of authigenic illite, was the only mineral recognized in the rest of the fine-grained rocks of the Alcotas Formation.

The original carbonate that precipitated in the calcareous horizons is replaced by coarse, euhedral to sub-euhedral dolomite and/or magnesite in most of the palaeosols. Alteration after sediment deposition, soil formation processes and subsequent stages of burial diagenesis hinder the recognition of original mineralogy of the carbonate present in some of the palaeosols. A possible carbonate precursor has been observed only in the Talayuelas section, where some nodules are composed of dolomicrite (Benito et al., 2005).

\section{Description and classification of palaeosols}

Six different pedotypes have been identified and carefully situated in their corresponding stratigraphic sections. General descriptions of the pedotypes are summarized in Table 1. Figure 4 includes a graphic representation of the palaeosols with mean grain-size and Munsell colour from field work, and two separate plots of mineral percentages obtained from point-counting data. The general classification and interpretation of the different pedotypes are summarized in Tables 2 and 3.

\section{Tabernilla pedotype}

\section{Description}

The Tabernilla pedotype shows two distinct horizons that define a thin profile up to $35 \mathrm{~cm}$ (Fig. 4A). The uppermost horizon is a layer $(<25 \mathrm{~cm})$ composed of red, massive mudstone with few light greenish-grey mottles of less than $5 \mathrm{~mm}$. The mudstone exhibits some vertical structures (35 cm in length and $0.5 \mathrm{~cm}$ wide) penetrating downwards with numerous horizontal branching. Such structures are interpreted as root casts. Thin sections show fractured quartz grains and strongly weathered feldspars within a reddish-brown clayey matrix. Clay coatings on the surface of detrital grains and areas with amorphous iron oxides are common features. The top of this layer is usually truncated by sandstone bodies with relict bedding. Downwards, this horizon passes gradually into the underlying massive, light red siltstone layer $(<15 \mathrm{~cm})$, which exhibits only a few carbonate nodules and veinlets (Fig. $5 \mathrm{~A}$ ), corresponding to an intermediate stage between I and II of the Machette (1985) classification. The carbonate nodules are $3 \mathrm{~cm}$ in diameter and exhibit coarse dolomite mosaics with some ovoid pores under microscopic observation. Gradually, the profile ends downwards into red mudstone and siltstone displaying clear cross-bedding structures.

\section{Classification}

The upper and clay-rich horizon of the Tabernilla pedotype is interpreted as being a zone of physical alterations and clay accumulation, and designated as a Cambic and B horizon (Fig. 4A). Although clay coatings on mineral grains are abundant, there is no indication of downward movement of clay and it cannot be interpreted as an argillic horizon. The presence of coarse dolomite and magnesite as small nodules and veinlets 


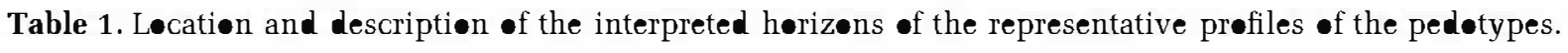

\begin{tabular}{|c|c|c|c|c|}
\hline Pedetype & $\begin{array}{l}\text { Section and } \\
\text { level }\end{array}$ & A herizen & B herizen & C hørizen \\
\hline Tabernilla & $\begin{array}{l}\text { Landete } \\
(6.75 \mathrm{~m})\end{array}$ & Net present & 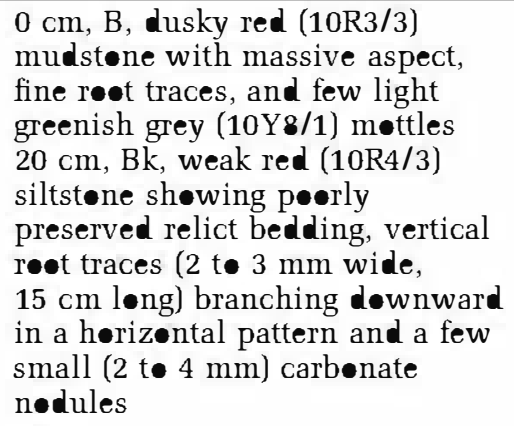 & $\begin{array}{l}32 \mathrm{~cm}, \mathrm{C}, \text { red }(10 \mathrm{R} 5 / 6) \\
\text { siltstene with clear relict } \\
\text { bedding }\end{array}$ \\
\hline R•den• & $\begin{array}{l}\text { Landete } \\
(33.4 \mathrm{~m})\end{array}$ & $\begin{array}{l}0 \mathrm{~cm}, \mathrm{~A} \text {, fine-grained } \\
\text { pinkish white }(10 \mathrm{R} 8 / 2) \\
\text { sandstene, with reot } \\
\text { trace up t } 1 \mathrm{~cm} \text { wide }\end{array}$ & 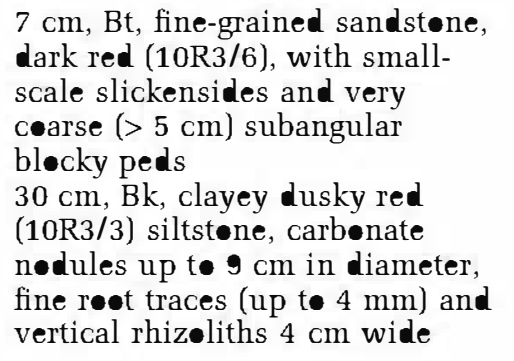 & $\begin{array}{l}54 \mathrm{~cm}, \mathrm{Ck} \text {, fine-grained } \\
\text { sandstene, weak red } \\
\text { (10R4/3), relict planar } \\
\text { bedding, calcare us }\end{array}$ \\
\hline Pedrizas & $\begin{array}{l}\text { Landete } \\
(\mathbf{1 7} .6 \mathrm{~m})\end{array}$ & Net present & 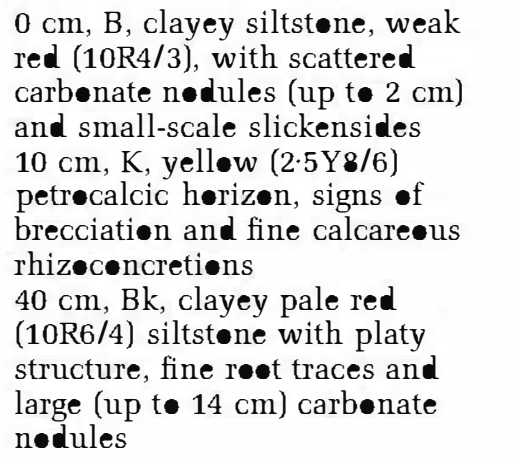 & $\begin{array}{l}66 \mathrm{~cm}, \mathrm{C} \text {, weak red } \\
(10 \mathrm{R} 5 / 4) \text { clayey } \\
\text { mudstøne with } \\
\text { small-scale slickensides }\end{array}$ \\
\hline Arenal & $\begin{array}{l}\text { Landete } \\
(69 \cdot 5 \mathrm{~m})\end{array}$ & 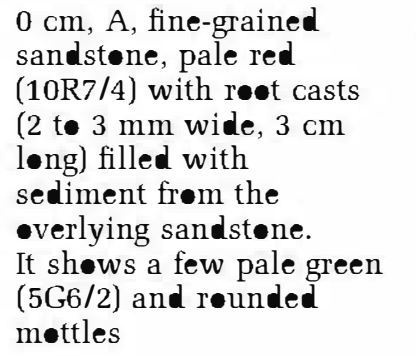 & Net present & $\begin{array}{l}30 \mathrm{~cm}, \mathrm{C} \text {, red }(10 \mathrm{R} 4 / 6) \\
\text { sandstene with abundant } \\
\text { mudcast and clear relict } \\
\text { bedding }\end{array}$ \\
\hline Asaderes & $\begin{array}{l}\text { Valdemeca } \\
(122.4 \mathrm{~m})\end{array}$ & $\begin{array}{l}0 \mathrm{~cm}, \mathrm{~A} \text {, light greenish } \\
\text { grey (10Y8/1) infilling } \\
\text { clastic dykes ( } 7 \mathrm{~cm} \text { wide } \\
\text { and } 30 \mathrm{~cm} \text { leng) intruding } \\
\text { in bluish grey mudst•ne } \\
\text { (5PB6/1) with well- } \\
\text { develøped slickensides }\end{array}$ & Net present & $\begin{array}{l}32 \mathrm{~cm}, \mathrm{C} \text {, dusky red } \\
(10 \mathrm{R} 3 / 6) \text { siltstene with } \\
\text { relict bedding and } \\
\text { small-scale slickensides }\end{array}$ \\
\hline Cerralizas & $\begin{array}{l}\text { Valdemeca } \\
(133.8 \mathrm{~m})\end{array}$ & $\begin{array}{l}0 \mathrm{~cm}, A \text {, very fine-grained } \\
\text { sandstene, dusky red } \\
(10 \mathrm{R} 3 / 4) \text {, with drab reot } \\
\text { traces }(10 \mathrm{GY} 7 / 1) 1 \mathrm{~cm} \text { wide } \\
\text { up te } 40 \mathrm{~cm} \text { leng }\end{array}$ & Net present & $\begin{array}{l}43 \mathrm{~cm}, \mathrm{C} \text {, medium- } \\
\text { grained sandstene, with } \\
\text { dusky red (10R3/6) celøur } \\
\text { and planar cress-bedding }\end{array}$ \\
\hline
\end{tabular}


A Tabernilla Pedotype

Field observations

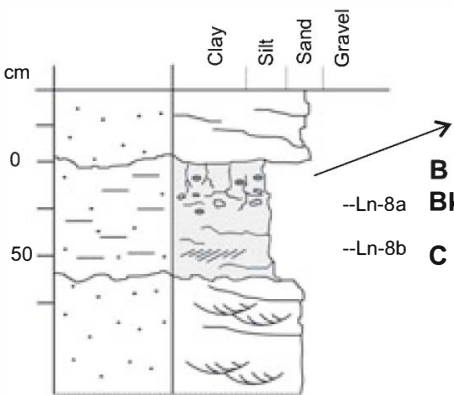

C Pedrizas Pedotype

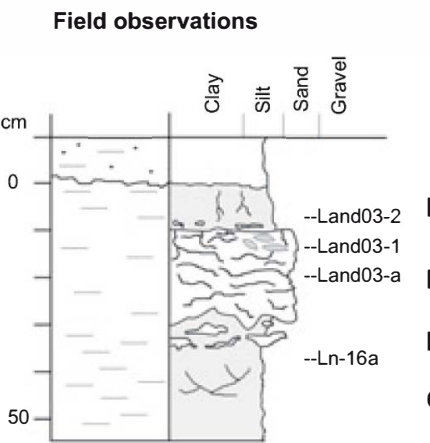

E Corralizas Pedotype

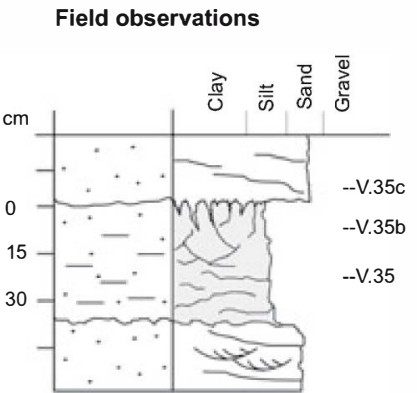

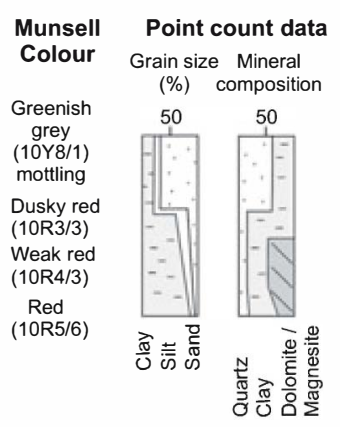

B

Weak red (10R4/3)

Yellow (2.5Y8/6)

Bk Pale red (10R6/4)

C Weak red (10R4/3)

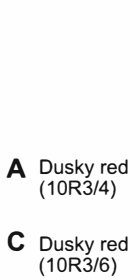

Munsell Colour
Point count data

Grain size Mineral

(\%) composition

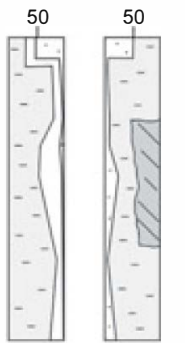

完蒜弯

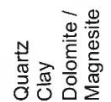

Point count data

Grain size Mineral

\section{B Rodeno Pedotype}

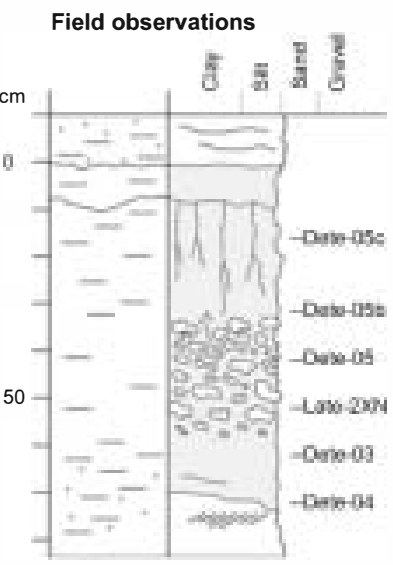

\section{Arenal Pedotype}

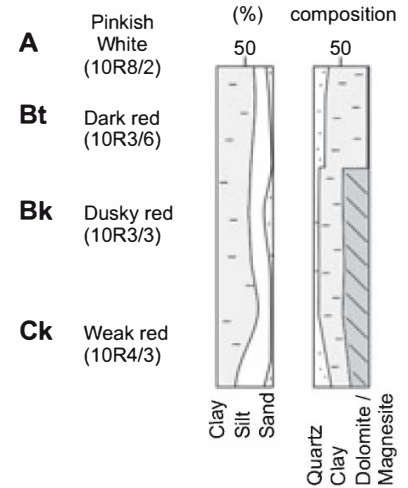

Field observations

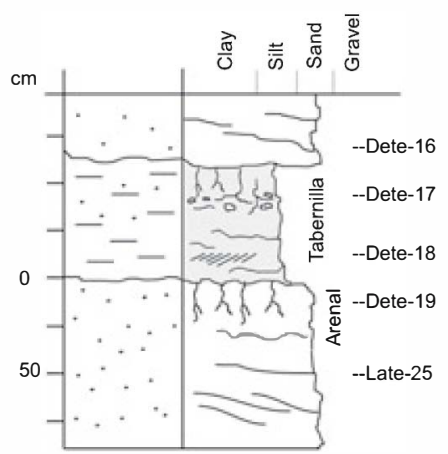

\section{F Asadores Pedotype}

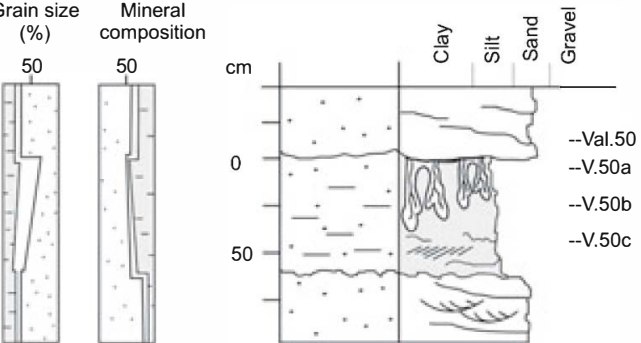

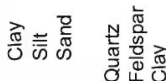

Munsell Colour

Point count data

Grain size Mineral

\%) composition

Munsell Point count data

Colour Grain size Mineral

(\%) composition

Red
$(10 R 4 / 6)$
Weak red
$(10 R 4 / 3)$
Light red
$(10 R 5 / 6)$

Pale red
$(10 R 7 / 4)$
Red
$(10 R 4 / 6)$

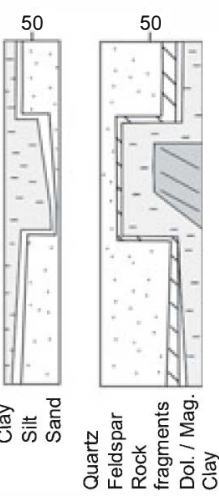

Munsell Colour

Point count data

Grain size Mineral

(\%) composition

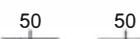

A Dusky red (10R3/4)

C Dusky red
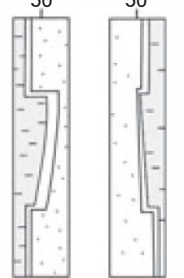

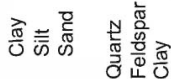

\begin{tabular}{|c|c|c|c|c|c|c|}
\hline \multicolumn{2}{|c|}{ Legend } & \multirow{2}{*}{ 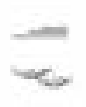 } & \multirow{2}{*}{$\begin{array}{l}\text { Planar lamination } \\
\text { Trough cross bedding }\end{array}$} & \multirow{2}{*}{$\therefore$} & \multirow{2}{*}{$\begin{array}{l}\text { Sulphate crystal pseudomorphs } \\
\text { Green mottling }\end{array}$} & \multirow{2}{*}{$\begin{array}{l}=\text { Carbonate nodules } \\
\text { Petrocalcic horizon }\end{array}$} \\
\hline$\because \because$ & Sandstone & & & & & \\
\hline$=7$ & Siltstone & $\approx$ & Planar tabular cross bedding & is & Root traces & mor Desiccation cracks \\
\hline$=-7$ & Shale, claystone & set- & Lateral accretion deposits & 83 & Drab-haloed root traces & $\downarrow \searrow$ Slickensides \\
\hline
\end{tabular}

Fig. 4. Measured sections of the different pedotypes in the Alcotas Formation with field observations, soil horizons, Munsell colours, grain-size and mineral composition. 


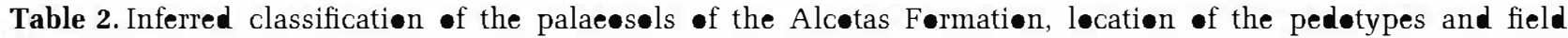
diagnesis.

\begin{tabular}{|c|c|c|c|c|c|}
\hline Pedotype & $\begin{array}{l}\text { Sectiøn } \\
\text { and level }\end{array}$ & Field diagnøsis & $\begin{array}{l}\text { Mack et al. } \\
\text { (1993) }\end{array}$ & FAO werld map & 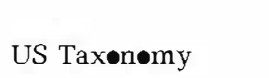 \\
\hline Tabernilla & $\begin{array}{l}\text { Landete } \\
(17.6 \mathrm{~m})\end{array}$ & $\begin{array}{l}\text { Small carbonate nodules and } \\
\text { veinlets }(\mathrm{Bk})<50 \mathrm{~cm} \text { deep at } \\
\text { stage I-II over red siltstone with } \\
\text { clear cross-bedding }\end{array}$ & Calcisøl & Calcic Cambis & Inceptis \\
\hline Røden• & $\begin{array}{l}\text { Landete } \\
(6.75 \mathrm{~m})\end{array}$ & 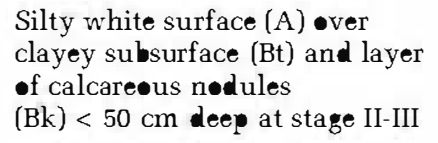 & Calcisøl & Calcic Xerøs & $\begin{array}{l}\text { Aridis } \bullet \\
\text { (Typic Hapløcalcid) }\end{array}$ \\
\hline Pedrizas & $\begin{array}{l}\text { Landete } \\
(33.4 \mathrm{~m})\end{array}$ & 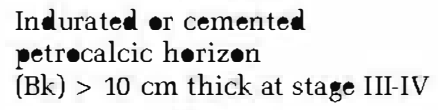 & Calcisøl & Calcic Xerøs•l & $\begin{array}{l}\text { Aridisøl } \\
\text { (Typic Petrøcalcid) }\end{array}$ \\
\hline Arenal & $\begin{array}{l}\text { Landete } \\
(69.5 \mathrm{~m})\end{array}$ & $\begin{array}{l}\text { Sandstone with root traces (A) } \\
\text {-ver bedded sandstone }\end{array}$ & Prøt•søl & Eutric Fluvisøl & Entisøl (Psamment) \\
\hline Cørralizas & $\begin{array}{l}\text { Valdemeca } \\
(122.4 \mathrm{~m})\end{array}$ & $\begin{array}{l}\text { Clayey surface (A) with } \\
\text { slickensides and lessicatiøn } \\
\text { cracks •ver red siltstønes }\end{array}$ & $\begin{array}{l}\text { Vertic } \\
\text { Pr•t•s} \bullet\end{array}$ & Eutric Fluvisøl & Entis•l (Fluvent) \\
\hline Asadores & $\begin{array}{l}\text { Valdemeca } \\
(133.8 \mathrm{~m})\end{array}$ & $\begin{array}{l}\text { Red siltstøne with distinct drab- } \\
\text { haløed røot traces }\end{array}$ & Prøt•søl & Eutric Fluvisøl & Entisøl (Fluvent) \\
\hline
\end{tabular}

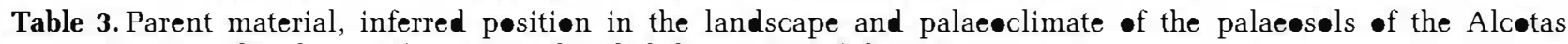

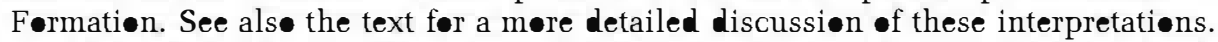

\begin{tabular}{|c|c|c|c|}
\hline Pedotype & Parent material & Landscape position & Palaeøclimate \\
\hline Tabernilla & $\begin{array}{l}\text { Crevasse and natural levée } \\
\text { deposits. Siltstønes and } \\
\text { fine-grained sandstones }\end{array}$ & $\begin{array}{l}\text { Raised levées banks and crevasse } \\
\text { leposits in a brøad, flat fløodplain }\end{array}$ & N• indicatiøn \\
\hline 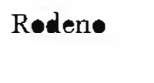 & $\begin{array}{l}\text { Overbank lepesits } \\
\text { Mudstønes and siltstønes }\end{array}$ & $\begin{array}{l}\text { High terraces and well-drained } \\
\text { deposits of the floodplain }\end{array}$ & $\begin{array}{l}\text { Arid t• semi-arid } \\
\text { Seasøally dry }\end{array}$ \\
\hline Pedrizas & $\begin{array}{l}\text { Overbank deposits } \\
\text { Mudstones and siltstones }\end{array}$ & $\begin{array}{l}\text { Flat, stable and seasønally } \\
\text { waterløgged fløodplain areas }\end{array}$ & $\begin{array}{l}\text { Arid t• semi-arid } \\
\text { Seasønally dry }\end{array}$ \\
\hline Arenal & $\begin{array}{l}\text { Filled abandoned channels and } \\
\text { crevasse deposits } \\
\text { Medium and fine-grained } \\
\text { sandstones }\end{array}$ & $\begin{array}{l}\text { Sandy stream banks, raised natural } \\
\text { levées and abandøned bars of the } \\
\text { løwland plain cl } \bullet \text { se to the main } \\
\text { river systems }\end{array}$ & N• indicatiøn \\
\hline Cørralizas & $\begin{array}{l}\text { Backswamp areas } \\
\text { Mudstones }\end{array}$ & $\begin{array}{l}\text { Small, muddy surfaces of } \\
\text { backswamp areas in the floodplain }\end{array}$ & Seasønally dry \\
\hline Asadores & $\begin{array}{l}\text { Overbank deposits } \\
\text { Mudstones and siltstones }\end{array}$ & $\begin{array}{l}\text { Frequently fløoded alluvial areas cløse } \\
\text { to the main river channel }\end{array}$ & N• indicatiøn \\
\hline
\end{tabular}

Fig. 5. (A) Small-scale nodules (n), veinlets (v) and reot traces ( $\mathrm{r}$ ) in an ereded prefile of the type Tabernilla

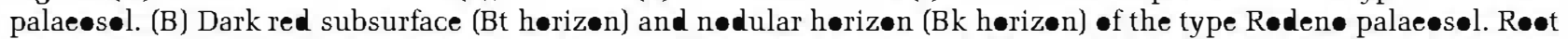
traces emanate frem the white surface interpreted as an A herizen (white arrøw). The scale bar is $15 \mathrm{~cm}$ løng.

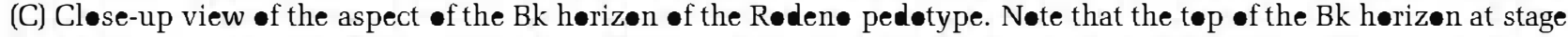

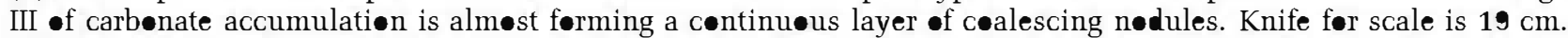
(D) Petrecalcic and nedular herizens of the type Pedrizas palaeesel in the Henarejes sectiøn. Centimetre-scale

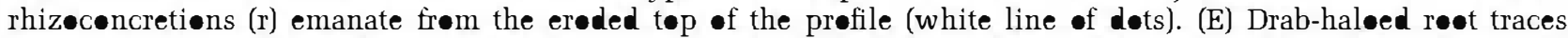

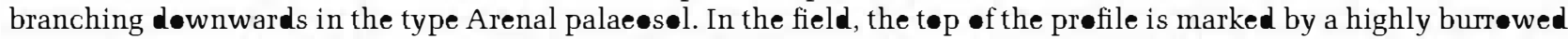
yelløw-brøwn surface (white arrøw and detted line). (F) Abundant burrews (b) and tubular structure (r) interpreted as

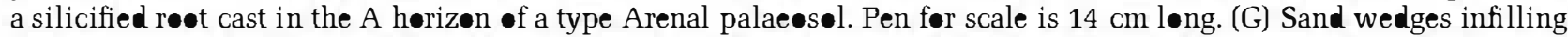

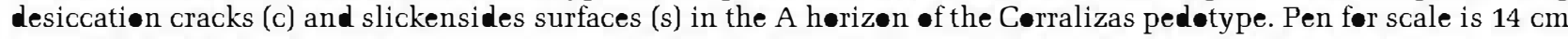

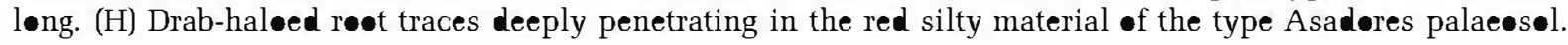



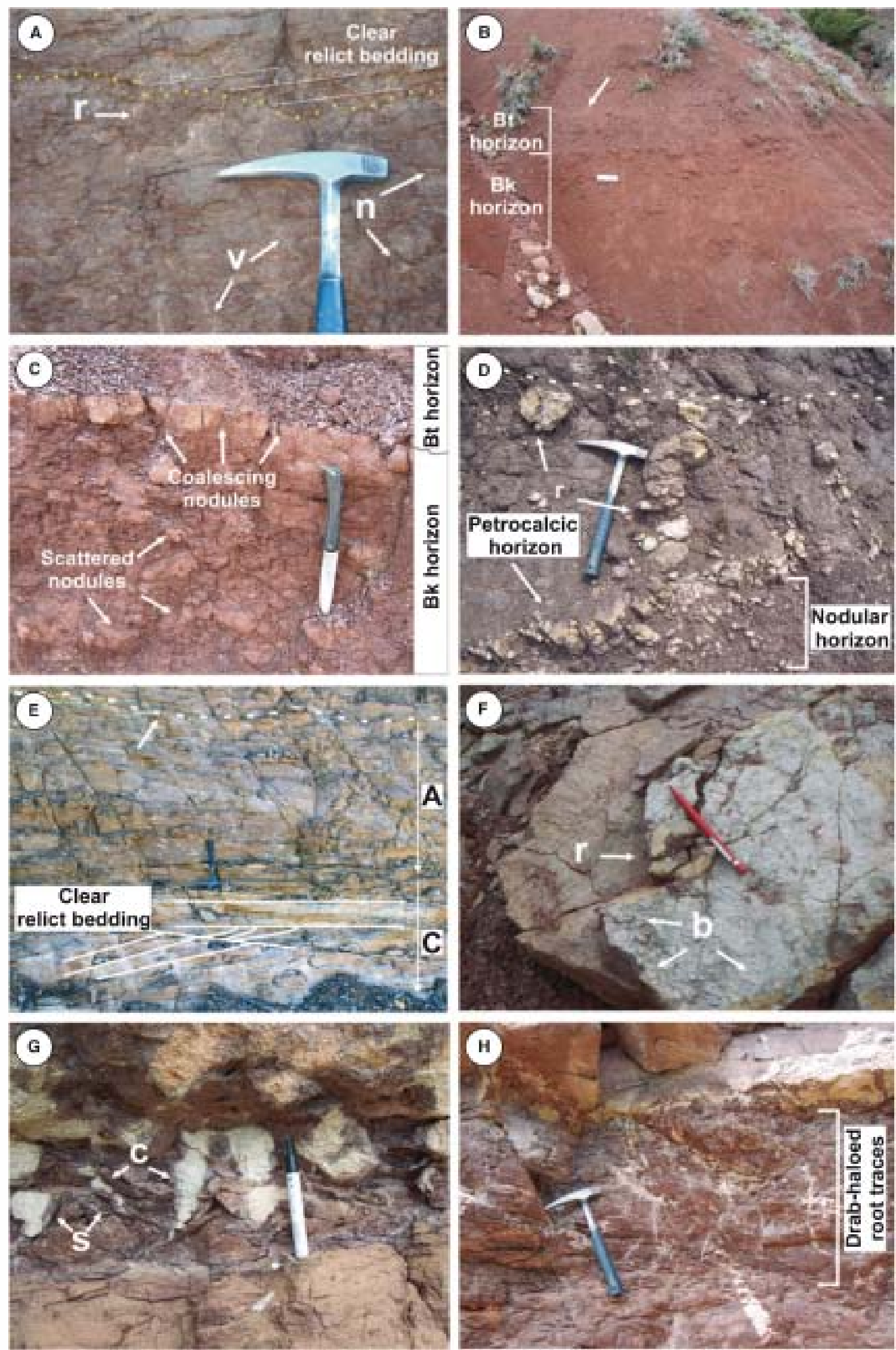
at less than $1 \mathrm{~m}$ depth is the most prominent pedogenic feature and permits this pedotype to be classified as Calcisol (Mack et al., 1993). However, the zone of carbonate accumulation is less than $15 \mathrm{~cm}$ thick, and it does not fulfil the requirements for its definition as a proper calcic horizon in the US Taxonomy. The type Tabernilla palaeosols could thus be classified as Inceptisols according to the US Taxonomy (Soil Survey Staff, 1999), as Calcic Cambisols (FAO, 1998) and Calcisols (Mack et al., 1993).

Based on root traces, mineral weathering and the clear stratification of the parent material (Retallack, 1988), the degree of carbonate accumulation (Gile et al., 1981) and because the formation of an argillic horizon requires at least a few thousand years (Soil Survey Staff, 1999), the Tabernilla palaeosols are considered as being weakly to moderately developed soils. The profiles of the Tabernilla palaeosols are usually truncated or buried by channellized sandstone bodies or crevasse-splay deposits related to the fluvial systems of the Alcotas Formation. Moreover, the green mottling, although not abundant, indicates weak waterlogging during some part of the year (Retallack, 2001). The Tabernilla palaeosols can be interpreted as formed upon topographically low areas of floodplains with frequent flooding.

\section{Rodeno pedotype}

\section{Description}

The Rodeno pedotype is developed within red to brown siltstone and mudstone with four horizons that represent a $70 \mathrm{~cm}$ thick profile (Figs $4 \mathrm{~B}$ and $5 \mathrm{~B}$ ).
The uppermost thin $(<10 \mathrm{~cm})$ and soft layer is composed of pinkish-white mudstone with centimetre-long root traces perpendicular to the surface of the profile. This layer shows an abrupt contact with the overlying siltstones and passes gradually downwards into the underlying purple to dark red, silty claystone, which exhibits root traces and poorly preserved platy and very fine $(<\mathbf{0 . 5} \mathrm{cm})$ sub-angular, blocky peds. This horizon is $25 \mathrm{~cm}$ thick and under microscopic observation displays a clay content of up to $70 \%$ in volume, clay coatings on mineral grains, clay laminations and oriented fillings of voids. Whole-soil coatings are also present; they formed by deposition of bands of silt and clay in the pore spaces after wetting of the soil and flowing down of a fine textured soil suspension (FitzPatrick, 1984).

In a gradual transition, marked by small and isolated carbonate nodules and veinlets, the Rodeno pedotype shows a horizon with scattered centimetre-scale nodules separated from each other by films of red clays. Internally, the nodules display a sub-angular blocky structure filled by crystals of coarse carbonate (Fig. 6A). Thin sections show that carbonate fills cracks and voids of less than $\mathbf{0} \mathbf{m m}$ width. This sub-angular, blocky structure surrounds clay-rich zones with detrital quartz and feldspar, and small-scale (up to $2 \mathrm{~mm}$ ) nodules with oxidized rinds (Fig. 6B). The petrographic studies and geochemical analyses reveal that the original mineralogy of the small-scale nodules has been replaced by coarse and euhedral to sub-euhedral, non-ferroan bright red luminescent dolomite and/or ferroan, dark-brown to non-luminescent magnesite that precipitated during subsequent stages of burial diagenesis

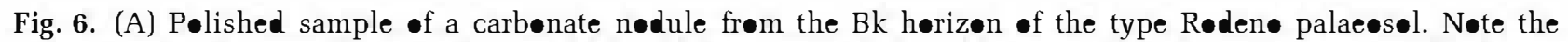

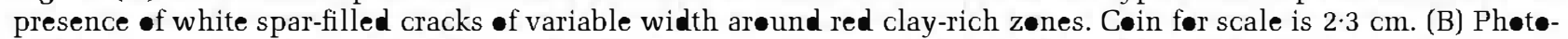
micregraph under plane-pelarized light of the same nedule ef (A) shøwing exidized rinds arøund small-scale nedules within a silty dark red greundmass with siliciclastic grains and spar-filled cracks. Scale bar is $\mathbf{1} \mathrm{cm}$.

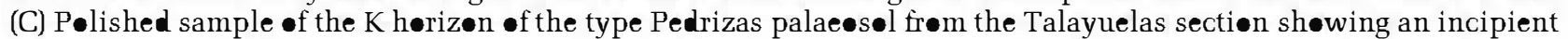

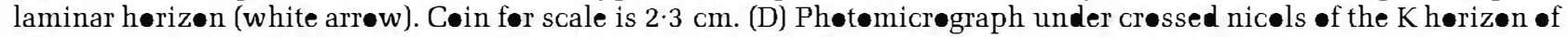

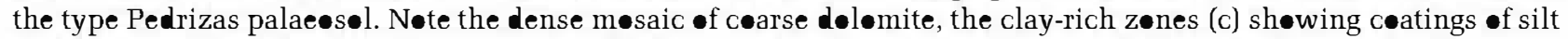

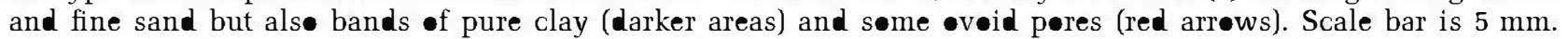

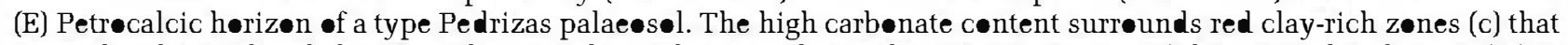
are is lated $\bullet r$ in bands between the crystals. In the central part the micritic texture ef the eriginal carbønate (m) is partially preserved, which is usually replaced by sparry magnesite $(\mathrm{sm})$ precipitated during late burial. The phøtemicregraph is under cressed nicels and the scale bar is $5 \mathrm{~mm}$. (F) Fragmented crystal ef feldspar (f) in the siliciclastic

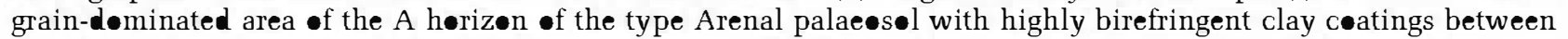

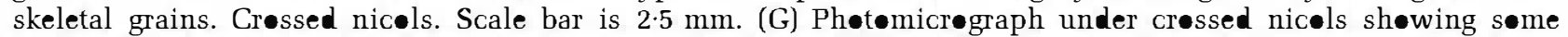
mederately altered crystals $\bullet$ quartz and ene strøngly altered feldspar (f) surreunded by red clay ceatings (c) in the A

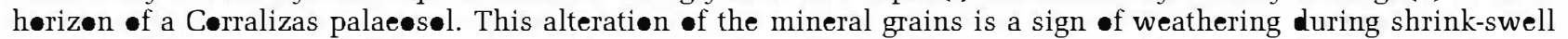

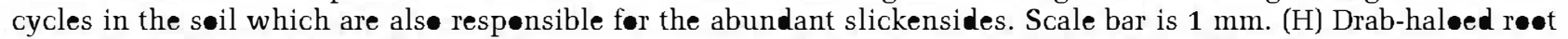

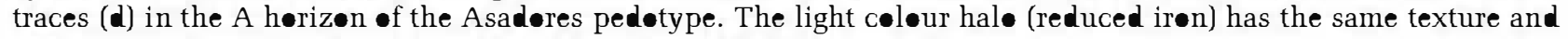
grain-size as the red seil matrix with exidized iren (c). Scale bar is $5 \mathrm{~mm}$. 

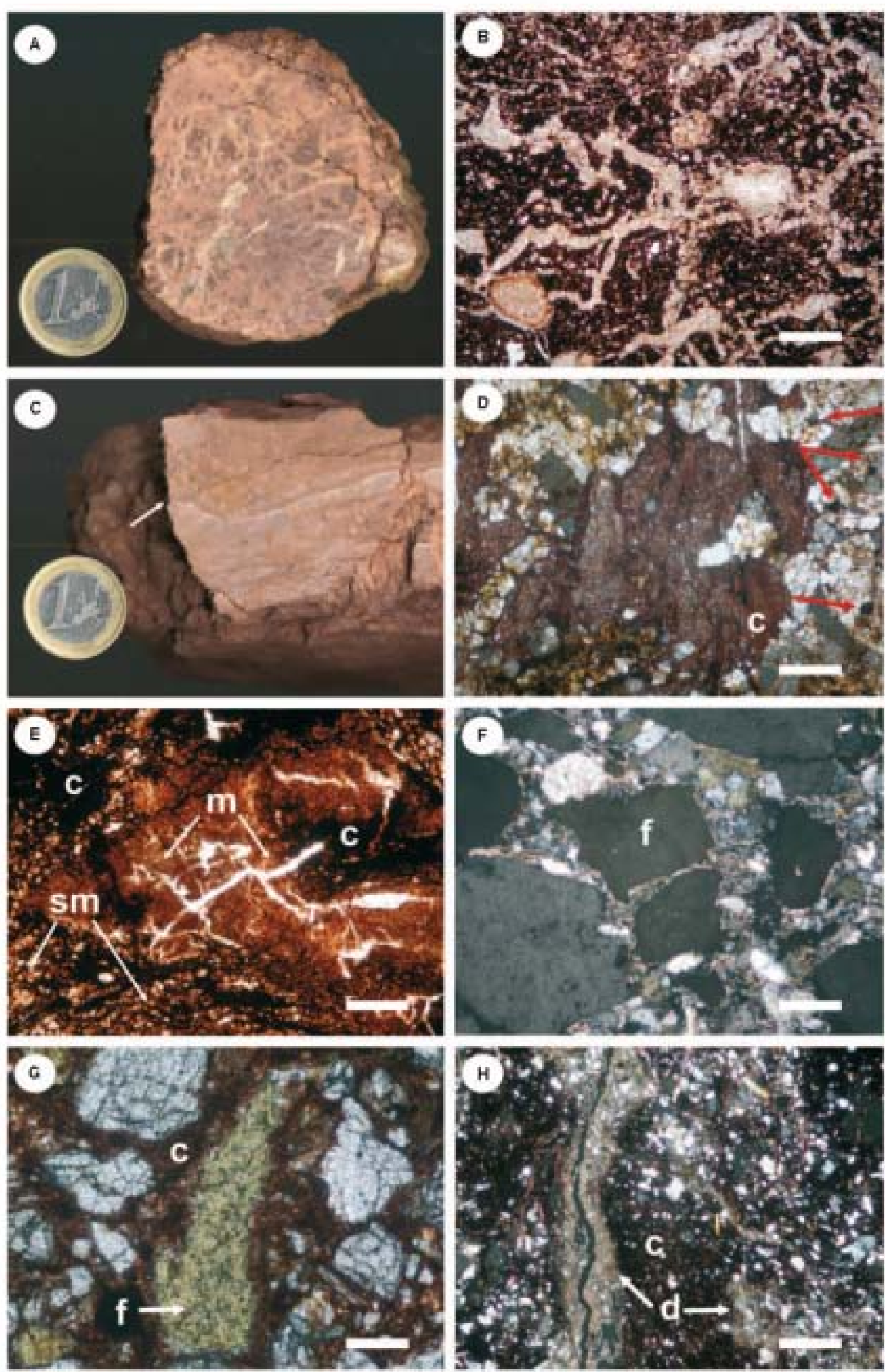
(Benito et l., 2005). In the uppermost part of this horizon, the nodules coalesce and form a continuous layer of carbonate nodules (Fig. 5C) reaching a morphological stage III of carbonate accumulation after the Machette (1985) classification. In the studied Rodeno palaeosols, the thickness of the nodular horizon varies between 25 and $96 \mathrm{~cm}$, and their lateral continuity ranges at least from 20 to $50 \mathrm{~m}$.

Finally, the lowest horizon is composed of red siltstone which shows relict primary bedding and gradational transition to the basal red siltstones of the host rock. In some cases, the skeletal grains of the siltstone appear to float in a dense dolomite mosaic.

\section{Classification}

Although no trace of organic matter can be found, the top of the Rodeno pedotype can be recognized as the horizon from which root traces emanate. This superficial layer is interpreted as the ancient A horizon (Figs 4B and 5B). The underlying red layer is a Bt horizon which shows voids with oriented clay fillings and whole-soil coatings as evidence of downward movement of clay. The stage III carbonate morphology of the Machette (1985) classification of the nodular horizon represents the Bk horizon.

Despite the original carbonate mineralogy of the Bk horizon being uncertain, the preservation of dolomicrite in some Bk horizons of the Rodeno pedotype is common in modern Aridisols under arid to semi-arid climate conditions (Sobecki \& Karathanasis, 1987; Wright \& Tucker, 1991; Spötl \& Wright, 1992; Alonso-Zarza, 2003; Retallack, 2004a; Benito et al., 2005; Khalaf, 2007). The abundant carbonate nodules at a shallow level $(<1 \mathrm{~m})$ in the Rodeno palaeosols characterize them as Typic Haplocalcids of the USDA Soil Taxonomy system (Soil Survey Staff, 1999) and Calcic Xerosols in the FA (1998) classification. Within the system specifically applicable to palaeosols, the Rodeno palaeosols are classified as Calcisols (Mack et l., 1993) based on their subsurface horizons enriched in carbonate.

The lack of noticeable soil organic matter in the A horizon and its light colour can be attributed to an overall decomposition of the organic carbon shortly after burial (Retallack, 1991). However, Aranda \& Oyonarte (2005) pointed out that a general characteristic of soils under a semi-arid climate is the low organic matter content in the surface soil horizons, which also reflects welldrained and aerated soils (Retallack \& AlonsoZarza, 1998). This observation is in agreement with the long root traces, the continuous and oriented clay coatings, the lack of redoximorphic features such as green mottling, and the downward movement and accumulation of secondary carbonate in the Bk horizon (Retallack, 2001). The presence of voids and cracks in a sub-angular, blocky structure is evidence of wetting and drying prior to the precipitation of the calcic infilling and the development of nodules (Tandon \& Gibling, 1997). The oxidized rinds around nodules (Fig. 6B) might indicate a fluctuation of redox conditions and may reflect distinct stages of development as a consequence of different climate conditions (Nahon, 1991; Retallack, 2001). The depth of the carbonate precipitation in a soil profile is related to the fluctuation of the wetting of the soil by available water and, therefore, is partially a function of rainfall (Royer, 1999). In well-drained soils of semi-arid regions only the surface of the soil is moistened by rain, and the carbonate precipitates near the depth of the average wetting. The precipitation of the carbonate is closer to the surface of the soil in dry seasons than in wetter seasons, and with high seasonal variations in rainfall, a thick carbonate horizon is formed (Retallack, 2005). Although the effect of burial compaction has not been corrected for, mostly all the type Rodeno palaeosols of the Lower Part display well-defined nodular horizons with an average thickness of $43 \mathrm{~cm}$ that could indicate a moderate seasonality in the climate. In the Henarejos and Talayuelas sections, however, thicker nodular horizons are observed in soils from the first few metres of the Lower Part, possibly related to a higher variation of rainfall between the dry and wet seasons.

\section{Pedrizas pedotype}

\section{Description}

Pale-red mudstones 8 to $17 \mathrm{~cm}$ thick occur at the top of the Pedrizas pedotype, forming a layer which is generally truncated by new accumulation of siltstone and exhibits a massive aspect with scarce root channels (Fig. 4C). Locally, thick and vertical structures composed of vertically stacked carbonate nodules are observed in this horizon (Fig. 5D). Small nodules of coarse dolomite $(<2 \mathrm{~mm})$ and pseudomorphs after sulphate crystals represent the transition with the underlying carbonate horizon (Benito et al., 2005; López-Gómez et al., 2005a). In the field, this horizon is distinctly recognized as a yellow, massive and indurated sheet of carbonate (>30 cm thick) which displays abundant cracks 
and an undulose and sharp top brecciated in places. The high carbonate accumulation fills most of the pores and other open spaces and results in a massive horizon similar to the plugged horizon of Gile et l. (1981). The plugged horizon develops in the last part of stage III of the Machette (1985) classification, although some Pedrizas palaeosols reach a morphological stage IV of the same classification, as the upper part of the solid carbonate layer has a weakly developed laminar structure (Fig. 6C). Occasionally, the upper zone of the carbonate horizon is composed of goethite, which preserves aggregates of lenticular pseudomorphs of siderite (Benito et al., 2005). Thin sections show red clays and siltstones within dense brownish-red dolomite and magnesite mosaics affected by fractures filled by ankerite, barite and ferroan calcite precipitated during burial. Clay and silt coatings, curvilinear circumgranular cracks and ovoid pores are the dominant pedogenic microfeatures (Fig. 6D and E).

The massive and indurated horizon passes gradually downwards into a layer consisting entirely of coalescing nodules up to $14 \mathrm{~cm}$ within pale red mudstone (Fig. 5D). These two horizons are clearly related and the presence of a massive carbonate horizon covering a nodular layer is a common feature in the Pedrizas palaeosols. Both the nodular and plugged horizons can be traced laterally several tens to hundreds of metres in the field, although changes in thickness are observed. The nodular layer displays a lower gradational contact with dark red and ferruginous mudstone which forms the parent material of the palaeosol.

\section{Classification}

The development of carbonate horizons has been related to the age of soil formation (Gile et al., 1981). Thus, with increasing soil age and continued carbonate accumulation, the spaces between peds, pores and other open spaces in the soil are filled with carbonate. The Pedrizas palaeosols represent the final step in the stage of carbonate accumulation represented by the morphogenetic sequence starting with the Tabernilla palaeosols. In this sequence, the few carbonate nodules and filaments, characteristic of the stage I to II Tabernilla palaeosols, develop to the prominent nodular Bk horizon of Rodeno palaeosols, reaching stage II to III. As discussed before, Tabernilla and Rodeno palaeosols are well-drained but, in the last part of stage III, the top of the Bk horizon is carbonate-impregnated, becoming a $K$ or petrocalcic horizon (Fig. 4C). At that point, the porosity is very low and the roots cannot easily penetrate downwards into the petrocalcic horizon. Stacked carbonate nodules form vertical and irregular tubules around the roots, which are interpreted as rhizoconcretions (Fig. 5D) or root-related accumulations of mineral matter (Blodgett, 1988). With decreasing porosity, the infiltrating water concentrates at the top of the petrocalcic horizon. As the water evaporates, sulphate crystals and new carbonate precipitate, forming a weakly laminar structure (Fig. 6C) and reaching the stage IV carbonate morphology of the Machette (1985) classification. In this final process, the upper laminae of carbonate are also the youngest.

The indurated carbonate accumulation of the Pedrizas pedotype forms a petrocalcic horizon within a depth of $1 \mathrm{~m}$ from the top of the profile. The Pedrizas pedotype is classified as a Typic Petrocalcid (Soil Survey Staff, 1999), Calcic Xerosol (FAO, 1998) and Calcisol (Mack et al., 1993).

Carbonate accumulations similar to those of Pedrizas palaeosols have been described previously and characterized as calcretes, laminar calcretes, rhizogenic calcretes or rootcretes (Jones, 1992; Mack \& James, 1992; Wright et al., 1995; Alonso-Zarza, 1999). There is a large consensus that the formation of laminar calcretes is owed to horizontal root systems, lichens, bacteria, fungi and other micro-organisms developed in stable surfaces of arid and semi-arid climates. This kind of vegetation could be more active during the humid periods in a semi-arid climate (Alonso-Zarza, 2003), and in more humid areas of the landscape. The laminar structure and the rhizoconcretions related to vertical roots of trees observed in some of the profiles suggest that Pedrizas palaeosols formed under wetter palaeoenvironmental conditions than the Rodeno palaeosols. In addition, the presence of siderite at the top of two Pedrizas palaeosols is in accordance with this assumption. In these cases, siderite precipitation possibly occurred in a very early diagenetic phase in which a table of stagnant water was covering the already buried soils (Retallack, 1997; Benito et al., 2005).

\section{Arenal pedotype}

\section{Description}

The Arenal palaeosols (Fig. 4D) commonly are developed over the medium-size sandstone bodies which occur interbedded within the fine-grained siltstone of the Alcotas Formation. The Arenal pedotype is composed of a yellow-orange 
coloured, massive sandy layer that passes downwards into light red sandstone with abundant relict bedding (Fig. 5E). The profile is $50 \mathrm{~cm}$ thick. The upper part is characterized by abundant and vertical burrows and drab light green coloured haloes that range up to $4 \mathrm{~cm}$ in diameter and penetrate 20 to $30 \mathrm{~cm}$ into the bedded horizon. Some of the haloes exhibit a reddish-brown interior surrounded by a drab colour, but they are more commonly preserved as impressions branching vertically into finer and denser mottling resembling root systems. Locally well-preserved circular and silicified structures with the interior filled with reddish fine-grained sandstone are found in some of the Arenal palaeosols, usually emerging from the top of the profile (Fig. 5F). Thin sections show granular microfabrics with slightly altered grains of feldspar and quartz that, in some places, are in contact with highly birefringent clay coatings partially filling intramineral cracks and the spaces among skeletal grains (Fig. 6F).

\section{Classification}

The Arenal pedotype represents very weakly developed sandy soils, with clear relict bedding and root traces (Figs 4D and 5E). Similar soils have usually been described and referred to the order Entisol of Soil Survey Staff (1999). The development of these kinds of soils does not allow determination of climatic conditions and, therefore, they are classified here as Psamments (Soil Survey Staff, 1999) based on sandy texture (Fig. 6F), Eutric Fluvisols (FAO, 1998) and Protosols (Mack et l., 1993). Retallack et al. (2002) pointed out that this kind of profile represents only a few seasons of plant growth in sandy alluvium.

The Arenal pedotypes in the Landete section are related to the important change in the fluvial style from sandy braided rivers to high sinuosity meandering rivers (Arche \& López-Gómez, 2005). In this part of the unit, sandy facies rapidly increase in abundance and more humid condi-

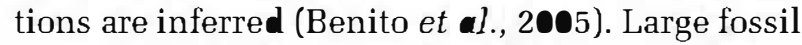
tree trunks (Diéguez \& López-Gómez, 2005), root traces and palynological assemblages (Diéguez \& Barrón, 2005) record the development of conifer forests in the banks of the meandering rivers where Arenal palaeosols are located.

\section{Corralizas and Asadores pedotypes}

\section{Description}

The Corralizas pedotype merges laterally into the Asadores pedotype in a few metres, indicating that these two types of palaeosols are closely related. Corralizas palaeosols are weakly developed within dusky-red mudstones (Fig. 4E); they show poor horizonation, large-scale slickensides, coarse angular blocky peds and vertical cracks (up to $9 \mathrm{~cm}$ wide and $17 \mathrm{~cm}$ long), displaying a typically V-shape and an irregular polygonal pattern in plan view. These cracks are filled by coarse sand from the overlying sandstone deposited on top of the profile (Fig. 5G), and are interpreted as being sand wedges infilling desiccation cracks that formed on flat and muddy surfaces (Allen, 1984). Reddish-brown root traces and some remains of organic matter are associated with the upper part of these silty-clayey soils. In thin section, feldspar grains appear moderately altered and surrounded by dark red clay coatings (Fig. 6G). The skeletal grains are floating or touching in point contact within a fine-grained matrix.

The Asadores pedotype (Fig. 4F) is developed on silty material and does not show distinctive horizonation, representing a weakly developed soil, with thicker profiles than those of the Corralizas pedotype. The uppermost $40 \mathrm{~cm}$ of the profile is massive but some polished striated surfaces ( $<15 \mathrm{~cm}$ long) and cracks up to $3 \mathrm{~cm}$ wide and $9 \mathrm{~cm}$ long can be observed. Distinct grey-green elongate zones, reaching $40 \mathrm{~cm}$ long, branch downwards from the upper part of the profile (Fig. $5 \mathrm{H}$ ). The size and abundance of the grey zones decrease significantly towards the lower part of the palaeosol, which clearly displays relict bedding and sandy texture. Under microscopic observation the grey-green irregular zones are often associated with vertical cracks (Fig. 6H).

\section{Classification}

The most clayey pedotype, Corralizas (Fig. 4E), has slickensides and cracks but does not reach the requirements for a Vertisol or Alfisol. The Corralizas palaeosols lack the argillic horizon required for Alfisols, and their profiles are not thick as in modern vertisols (Retallack, 2001). The profile type is thin $(<50 \mathrm{~cm})$, shows poor horizonation, and the $\mathrm{V}$-shaped cracks are the most prominent feature (Fig. 5G). Because of their slight degree of soil formation, Corralizas palaeosols are referred to the orders Entisol (Soil Survey Staff, 1999) and Protosol (Mack et al., 1993). More specifically, the Corralizas palaeosols are comparable to modern Fluvents (Soil Survey Staff, 1999) and Eutric Fluvisols (FAO, 1998) formed in alluvial floodplains dissected by 
fluvial channels. However, vertic properties observed in this pedotype allow it to be classified as a Vertic Protosol in the classification system of Mack et $\boldsymbol{a l}$. (1993).

The elongated and branching-shape green-grey zones observed in the red silty Asadores pedotype are interpreted as drab-haloed root traces (Fig. 5H). Such drab root traces can be formed around decaying organic matter under reducing conditions occurring shortly after burial of the soil (Blodgett, 1988; Retallack, 1991); however, drab surfaces are also present in soil cracks within the red matrix, which can be evidence of waterlogging (Kraus, 1996; Retallack, 2001). The lack of a gleyed horizon and the deeply penetrating root traces indicate moderate to good drainage conditions (Alonso-Zarza, 2003; Retallack, 2004b). Thus, Asadores palaeosols were not permanently waterlogged throughout the year. The Asadores pedotype is classified as Gleyed Protosol (Mack et al., 1993), Fluvents (Soil Survey Staff, 1999) and Eutric Fluvisols (FAO, 1998).

\section{PALAEOENVIRONMENT AL RECONSTR UCTION}

\section{Palaeosol development along the Alcotas Formation: palaeoenvironmental significance}

Care must be taken when interpreting palaeoenvironmental aspects by using only pedotype characteristics, as there are many different controls on pedogenic processes (Alonso-Zarza et al., 1999; Kraus, 1999; Alonso-Zarza, 2003; Retallack, 2004b), and especially those related to palaeosol maturity which is inversely related to sedimentation rate (Bown \& Kraus, 1987). Extrinsic factors, such as eustacy and tectonics, are also important as they can affect the base level (Posamentier \& Allen, 1999) and therefore the development of pedogenic processes. During the Late Permian, the Iberian Basin was far away from the influence of the Palaeotethys (Fluteau et al., 2001; Stampfli \& Borel, 2002; López-Gómez et al., 2005b) which minimizes the possible role of eustatic control. Tectonism was a key factor controlling the sedimentation rate. Studies of the tectonic history during the Late Permian (Sopeña et al., 1988; Arche \& López-Gómez, 1996, 1999; López-Gómez \& Arche, 1997; Van Wees et al., 1998; Vargas, 2002) demonstrate that the Alcotas Formation sedimentation represented a time of relatively constant subsidence and moderate sedimentation rate (about $1 \mathrm{~cm}$ per 10 years).
The development and accumulation of the palaeosols described here show a general distribution by geographical area during the time of sedimentation of the Alcotas Formation (Fig. 7). The Pedrizas palaeosols are located in the central area of the studied basin as dispersed zones that are larger and more abundant in the uppermost sediments of the Lower Part. The Rodeno and Tabernilla pedotypes also are located in the central area of the basin around the Pedrizas pedotype, mostly in the Lower Part. The noncalcareous Arenal palaeosols occur around the other pedotypes, occupying most of the rest of the Lower Part, and extending upwards into the Middle Part. Finally, the Upper Part is characterized mainly by the lack of palaeosols, with the Asadores and Corralizas pedotypes occurring in the uppermost part of the Alcotas Formation and restricted to the western area of the basin. Information about the tectonic control on the sedimentation of the Alcotas Formation (Arche \& López-Gómez, 1996, 1999, 2005) and the main sedimentological and mineralogical characteristics of the Lower, Middle and Upper Part (Benito et al., 2005; López-Gómez et al., 2005a) are used here for studying the relationship between the described palaeosols and the Late Permian sedimentary record of the Alcotas Formation.

\section{Lower Part}

The Lower Part has been interpreted as sandy to gravelly braided fluvial deposits with a high avulsion rate embedded in a wide, fine-grained floodplain (Arche \& López-Gómez, 2005). However, the presence of the well-developed Pedrizas palaeosols implies that, during short periods of landscape stability, the sedimentation rate was slow relative to rates of pedogenesis. The formation of similar soils has commonly been associated with arid to semi-arid climates (Alonso-Zarza, 2003), which agrees with the high carbonate accumulation and the presence of pseudomorphs of sulphate crystals. Occurrence of evaporites points to a very dry climate but could only indicate a high evapotranspiration rate during some seasons of the year. In fact, the Pedrizas palaeosols could be formed under more humid conditions within an arid to semi-arid climate based on the presence of abundant centimetre-scale rhizoconcretions, horizontal root systems and laminar structure. The more humid conditions are also supported by the stratigraphic position of the Pedrizas palaeosols. These palaeosols are very frequent near the transition between the Alcotas Formation and the 


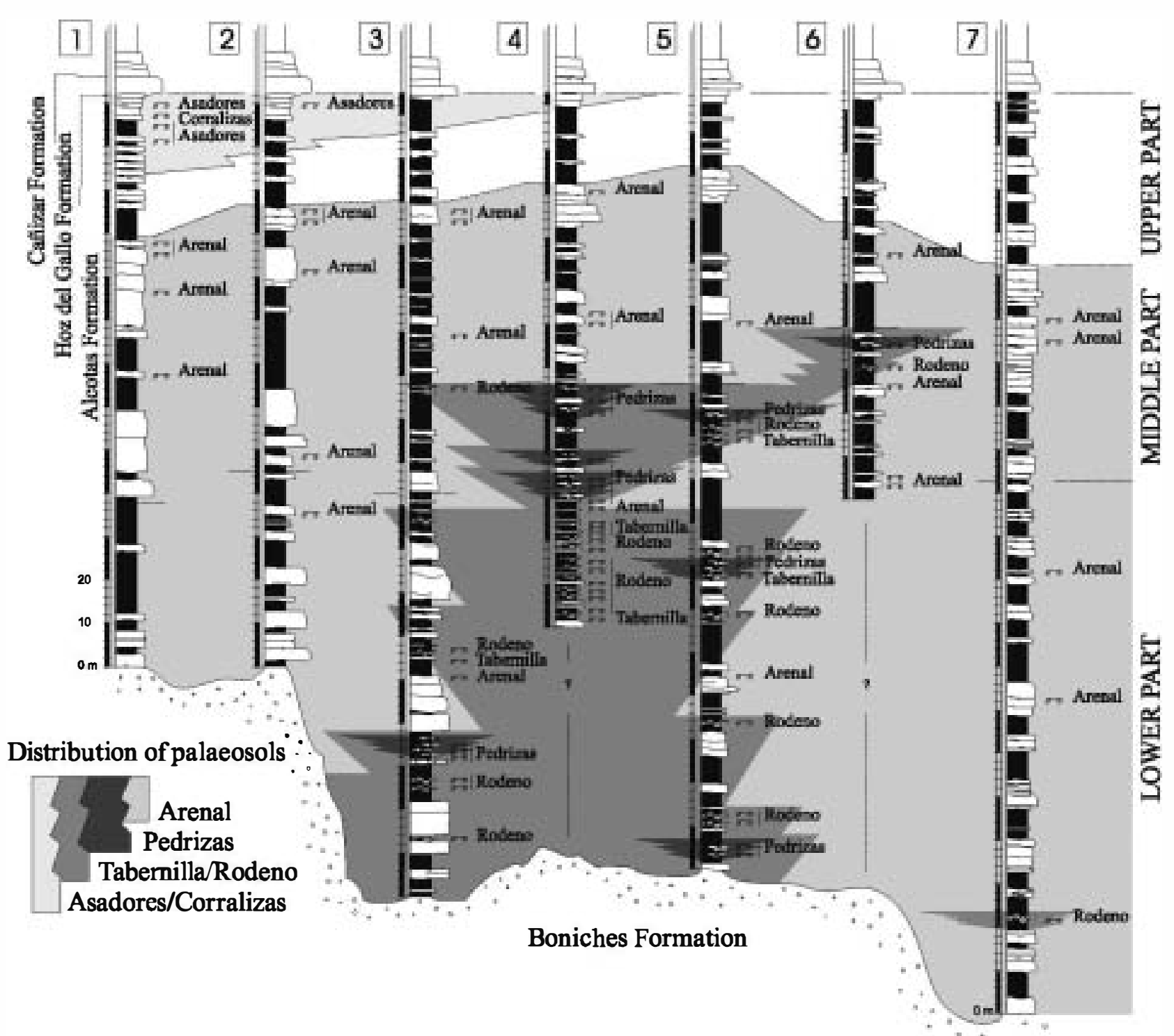

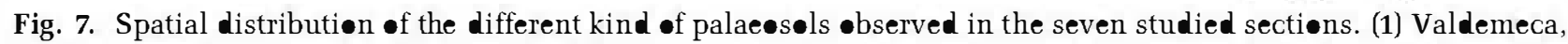

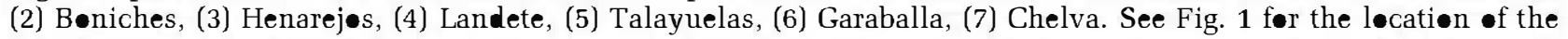
sections.

immediately underlying Boniches Formation, which is formed under humid conditions in an equatorial zone dominated by monsoon and seasonal regimes (López-Gómez \& Arche, 1997; López-Gómez et al., 2005b). Following examples described by Retallack (2001), the kaolinite content observed in the fine-grained deposits of the transition between the Alcotas and Boniches Formations (Alonso-Azcárate et al., 1997) could correspond to soils that receive more than $500 \mathrm{~mm}$ mean annual precipitation. In the last upper metres of the Lower Part of the Alcotas Formation (Fig. 3), the presence of siderite in some of the Pedrizas palaeosols (Benito et al., 2005) has been related to a very early diagenetic phase precipitated under marsh and swamp deposits in floodplains as described by different authors in similar environments (Coleman, 1985; Curtis \& Coleman, 1986; Hornibrook \& Longstaffe, 1996; Mackay \& Longstaffe, 1997). In these cases, siderite occurrence also suggests periods of waterlogging and humid conditions.

The Rodeno/Tabernilla association developed in surfaces with extensive sub-aerial exposure that favoured the development of carbonate nodules in which the preservation of dolomicrite indicates that they originally developed as dolocretes in an arid to semi-arid climate with marked seasonality (Wright \& Tucker, 1991; AlonsoZarza, 2003). Differences between dry and wet 
seasons were responsible for the fluctuation of wetting in the soil by available water and the formation of the nodular horizons of the type Rodeno palaeosols. These differences are more noticeable in the first metres of the Lower Part where the nodular horizons are thicker.

The horizontal distribution of the palaeosols of the Lower Part in the basin correlates well with topography (Figs 7 and 8). The Tabernilla palaeosols were formed mainly in areas with high sedimentation rates, localized close to natural levées or affected by crevasse deposits. The Rodeno profiles developed in higher floodplain areas distal to the active channel. Finally, the Pedrizas palaeosols occur in floodplain areas far away from the activity of the channel fluvial systems, in stable and flat landscapes with low sedimentation rates (Fig. 8). With increasing time, Pedrizas palaeosols develop an indurated carbonate layer that can form a barrier to further percolation of water and favoured wet areas during short periods of time.
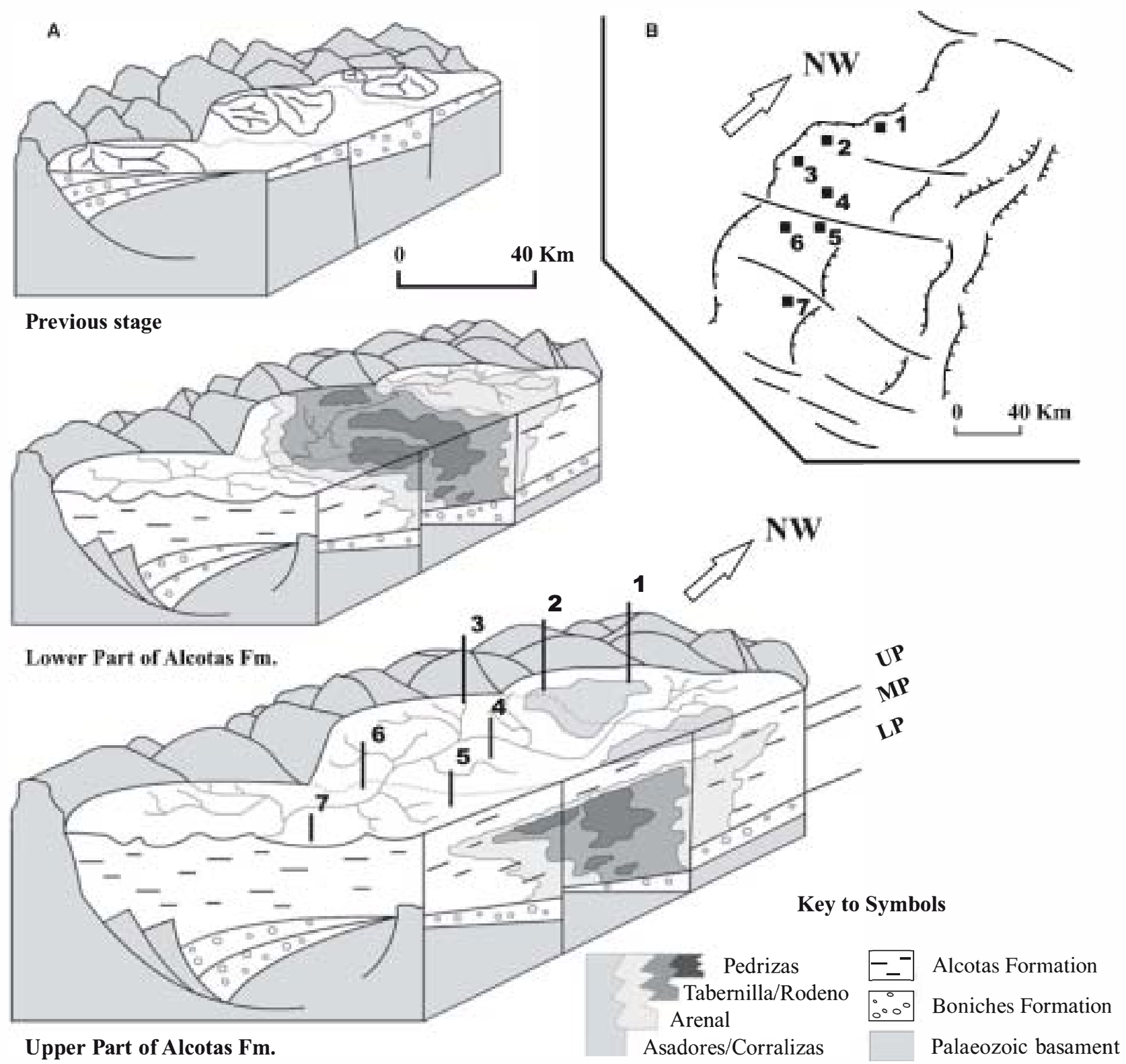

Fig. 8. (A) Tectonic sketch showing the spatial distribution and development of the palaeosols during the sedimentation of the Alcotas Formation. (B) Reconstruction of the basin boundary faults during the Late Permian. Note the two main NW-SE and SW-NE thrust systems. See Fig. 1 for the location of the sections. Tectonic sketches are based on Arche \& López-Gómez (1996, 1999). 
Climatic changes, however, could be responsible for the vertical distribution of the Pedrizas palaeosols shown in Fig. 7; their presence, in the first metres of the Lower Part of Alcotas Formation, indicates a climatic drying from the humid conditions of the Boniches Formation. With increasing aridity reaching its maximum at the middle of the Lower Part, Pedrizas palaeosols are absent, returning in the last metres of the Lower Part with wetter conditions. This climatic trend is supported by mineralogical evidence. A change from kaolinite to illite is recorded in the transition between the Boniches and Alcotas formations (Alonso-Azcárate et al., 1997). Kaolinite is common in sediments of humid climates, with heavy rains and moderate to high temperature. Illite, the dominant clay component in the palaeosols of the Lower Part, is mostly detrital in origin. It was formed as a consequence of long weathering processes in the high metamorphic-granitic source area to the NW under semi-arid and seasonal conditions (Alonso-Azcárate et al., 1997). Another possibility for the origin of illite, pointed out by these authors, implies high erosion rates under arid and semi-arid conditions in coeval deserts, and sediment transportation by wind as demonstrated by Jeans et al. (1994) for Permian-Triassic rocks from the south Devon coast (UK). Incoming windblown dust could be responsible for the high carbonate content in the palaeosols of the Lower Part, which is in agreement with other sedimentary rocks in some Permian-Triassic western European basins (Lucas, 1962; Fisher \& Jeans, 1982). However this suggestion has been, until now, difficult to prove.

The above-mentioned interpretation of the palaeoenvironmental evolution is in accordance with the quantitative analysis of palynomorphs carried out by Diéguez \& Barron (2005). The pollen assemblage studied in the middle of the Lower Part corresponded to the Klausip-llenitesLueckisporites association, and represents a conifer forest dominated by members of the Ullmaniaceae, Pinopsida and Majonicaceae. The observed low population density indicates that it was a depauperate and oligotrophic forest, with scattered trees and shrubland vegetation (pteridosperms and gnetopsids) almost absent. The fluvial architecture and style of highly mobile braided sandy systems dominated by flash-floods could be, in part, responsible for the low vegetation density, although the avulsion process could also be favoured by the existing depauperate forest and the reduced vegetation cover (Michaelsen, 2002).
Middle Part

This part shows a drastic lithological change with respect to the Lower Part. The thick pile of sandstone bodies separated by decimetre-thick intervals of siltstone beds is interpreted as meandering river deposits (Arche \& López-Gómez, 2005). This change in the fluvial style coincides with the presence of abundant plant remains, fossil tree trunks in the base of the channels, traces of pyrite and coal flakes, and erosion and reactivation surfaces. These features can also be found in coeval formations from places as far away as Australia, South Africa and Brazil (Smith, 1995; Ward et al., 2000; Miall \& Jones, 2003; Smith \& Botha, 2005).

Arenal pedotype is the predominant pedotype found in the Middle Part. Only one weakly developed carbonate Tabernilla palaeosol is found in the Middle Part of the Henarejos section. Arenal palaeosols are weakly developed in the sandy alluvium of banks and fluvial-bars of the meandering system in which conifer forests established. Palynological associations have recently been studied in this part of the Alcotas Formation (Diéguez \& Barron, 2005). Results indicate a tendency to more humid conditions starting in the upper metres of the Lower Part and continuing until the top of the Middle Part. The presence of carbonaceous shales and coal flakes is in agreement with the inferred humid environment of the Middle Part. This part shows strata with a high concentration of fossil trunks with sporadically well-preserved specimens, some of them described as Dadoxylon sp. (Diéguez \& López-Gómez, 2005) and Ullmania sp. (Doubinger et $a$ l., 1990), suggesting the development of a conifer forest with a dense shrubland vegetation. However, Diéguez \& Barron (2005) identified the lack of transitional floras and an important dieback of diversity and decline of population indicating, at least, a local biotic crisis prior to the Permian-Triassic Boundary.

\section{Upper Part}

In the Upper Part of the Alcotas Formation, the style of the fluvial system is associated with the very low energy of a sandy braided river with a high avulsion rate and marked seasonality (Arche \& López-Gómez, 2005). No plants or palynological assemblages have been found up to now (López-Gómez et al., 2005a). The Upper Part does not show palaeosols except locally some Corralizas and Asadores pedotypes at the uppermost part and close to the main basin faults (Fig. 7). The absence of palaeosols agrees with the local 
biotic crisis that occurred at the end of the Middle Part and with the above described barren interval of the Lower Part. In fact, the occurrence of the Corralizas and Asadores pedotypes could indicate a later, brief and weak recuperation of the vegetation. These soils developed on floodplains of very flat topography where lateral changes between the two soils are related to the position in the fluvial system. Corralizas palaeosols were situated in clayey backswamp and poorly vegetated areas not too far from the main river channels. The silty pedotype Asadores probably developed closer to the fluvial system and it displays penetrating root traces indicating good drainage and more favourable conditions for vegetation growth.

\section{Tectonic evolution and soil development}

Well-constrained subsidence rates history and general tectonic evolution of the SE Iberian Ranges during the Late Permian (Salas \& Casas, 1993; Arche \& López-Gómez, 1996) point to a basin development in different asymmetrical half-grabens that represent a succession of segments of 40 to $60 \mathrm{~km}$ long (Fig. 1). The NW-SE listric fault system forms semi-connected neighbouring half-grabens that are separated by the secondary NE-SW transfer fault system. Polyphase rifting during the tectonic development of the SE Iberian Basin in the Late Permian (Van Wees et al., 1998; Vargas, 2002) conditioned the sediment accumulation rates and, therefore, the palaeosol development. The studied basin shows clear evidence of this asymmetry in its evolution during the Late Permian. Figure 8 shows a sketch of this asymmetrical evolution and its relationship with the palaeosol distribution shown in Fig. 7 .

In the Lower Part of the Alcotas Formation, the mature and carbonate-rich (i.e. Pedrizas) palaeosols occur at the basin centre (Fig. 8). Rodeno and Tabernilla palaeosols, which needed shorter time for their development, occur around the Pedrizas soils and they are, in turn, surrounded by the better-drained, sandy Arenal palaeosols.

The Middle Part is characterized by high avulsion rate meandering systems and some swamp environments formed in the central and low slope area during relatively slow subsidence (Arche \& López-Gómez, 2005). Palynomorph assemblage data obtained from the uppermost sediments of the Middle Part indicate a clear spreading of humid places (Diéguez \& Barron, 2005). These general conditions could explain the lack of carbonate palaeosols in this Middle Part.

Finally, in the Upper Part, after an initial period of high sedimentation rate characterized by the complete absence of macroflora or microflora and palaeosols, the Corralizas and Asadores pedotypes developed close to the NW border of the basin during the latest stages of the Alcotas Formation sedimentation. These higher areas close to the border of the basin were probably more receptive to the rain waters generated by the moisture of the Tethys sea (Fluteau et al., 2001).

In general, the development of tectonic phases in the SE Iberian Basin during the Late Permian fits with the three-fold subdivision established for the Alcotas Formation. The sedimentation rate in the Lower Part was probably steady, although the rate of pedogenesis exceeded the rate of deposition, and mature palaeosols (i.e. Pedrizas) developed. In the Middle Part the sedimentation rate decreased, due to a drop in the subsidence rate and in connection with a climatic change towards more humid conditions. Finally, a progressive warming in the climate with reduced and sporadic sediment supply is inferred for the uppermost sediments of the Upper Part. Although palaeosols are useful in determining changes in relative rates of sediment accumulation, controlled by both intrabasinal and extrabasinal factors (Kraus, 1987), the most important characteristics of the different palaeosols also require key factors other than parent material, time or tectonism for their development. Changes in the climate might provide an alternative explanation for the differentiated evolution of the Iberian Basin during the Late Permian.

\section{CONCLUSIONS}

The study and interpretation of Late Permian palaeosol profiles in the South-East Iberian Ranges, Spain, confirms previous palaeoenvironmental reconstructions based on other lines of evidence such as significant changes in fluvial style, vegetation biodiversity or mineralogical characteristics which are related to intrabasinal or extrabasinal causes. The different stages of the asymmetrical evolution of the SE Iberian Basin during the Late Permian are reflected in the palaeogeographical distribution of the palaeosols into the studied area. This distribution suggests topographic, climatic and tectonic controls. 
During the Wuchiapingian, the SE Iberian Basin experienced a progressive tendency towards more arid conditions from a humid climate with high precipitation rates and marked seasonal regimes under which the Boniches Formation was deposited. These more arid conditions were suitable for the development, in the Lower Part of the Alcotas Fm., of the Pedrizas, Rodeno and Tabernilla pedotypes. This tendency was interrupted by a humid episode that coincides with the general basin reorganization and an important change in the fluvial style from braided rivers into meandering systems. This humid episode is characterized by the lack of carbonate palaeosols, and the presence of coal layers and carbonaceous shales. Only the Arenal pedotype developed in the sandy alluvium of the meandering system. The biotic crisis documented during this humid episode, prior to the Permian-Triassic Boundary extinction event, was followed by a barren zone with a new change in the fluvial style to a lowenergy sandy braided river system with a high avulsion rate and where no palaeosols or macroflora or microflora have been found. Finally, the presence of the Asadores and Corralizas pedotypes indicates a local and weak recuperation of the vegetation in the last upper metres of the Late Permian sedimentary record.

The characteristics observed in the continental deposits of the SE Iberian Basin during the Late Permian reveal a climatic trend of general aridization interrupted by a short phase of increased humidity which probably is related to an important biotic crisis. This trend has been documented in other European Permo-Triassic basins and is in agreement with a gradual chain of events of drastic consequences prior to the well-documented Permian-Triassic extinction event.

\section{ACKNOWLEDGEMENTS}

The authors thank the anonymous reviewers who contributed greatly to improve the quality of the manuscript. We are grateful to Dr Ana AlonsoZarza who provided numerous thoughtful and constructive comments since the beginning of this study. Gilberto Hernández carefully elaborated numerous difficult petrographic thin sections, and Modesto Escudero helped with some illustrations. We specially thank Dr Greg Retallack for the use of his laboratory and for his helpful advice and kind hospitality at the University of Oregon. Financial support was provided by project CGL2005-01520/BTE of the
Spanish Ministry of Education and Science and the Research Groups of Sedimentary Basin Analysis and Palaeoclimatology and Global Change of the University Complutense of Madrid.

\section{REFERENCES}

Allen, J.R.L. (1984) Sedimentary Structures: Their Character and Physical Basis, Vøl. 2. Elsevier, Amsterdam, 663 pp.

Alonse-Azcárate, J., Arche, A., Barrenechea, J.F., López-Gómez, J., Luque, F.J. and Rødas, M. (1997) Palae@geøgraphical significance of clay mineral assemblages in the Permian and Triassic sediments of the SE Iberian Ranges. Palaegeogr. Palaeclimat l. Palaevecl., 136, 309-330.

Alonsø-Zarza, A.M. (1999) Initial stages of laminar calcrete formation by røots: examples from the Neøgene of central Spain. Sed. Geol., 126, 177-191.

Alønse-Zarza, A.M. (2003) Palaevenvirønmental significance -f palustrine carbonates and calcretes in the geoløgical rec•r. Earth-Sci. Rev., 60, 261-298.

Alønsø-Zarza, A.M., Søpeña, A. and Sánchez-Møya, Y. (1999)

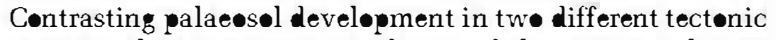
settings: the Upper Buntsandstein of the western Iberian ranges, central Spain. Terr Nøva, 11, 23-29.

Aranda, V. and Oyonarte, C. (2005) Effect of vegetation with different evølution degree on søil •rganic matter in a semiari environment (Cabo de Gata-Níjar Natural Park, SE Spain). J. Arid Envir•n., 62, 631-647.

Arche, A. and López-Gómez, J. (1996) Origin of the PermianTriassic Iberian Basin, central-eastern Spain. Tectonøphsics, 266, 443-464

Arche, A. and López-Gómez, J. (1999) Subsidence rates and fluvial architecture of rift-related Permian and Triassic alluvial sediments of the southeast Iberian Range, eastern Spain. Int. Assøc. Sediment•l. Spec. Publ. 28, 283-304.

Arche, A. and López-Gómez, J. (2005) Sudden changes in fluvial style across the Permian-Triassic boundary in the eastern Iberian Ranges, Spain: analysis of possible causes. Palaengeogr. Palaeoclimat॰l. Palaevec l., 229, 104-106.

Benite, M.I., De la Horra, R., Barrenechea, J.F., López-Gómez, J., Rødas, M., Alonsø Azcárate, J., Arche, A. and Luque, F.J. (2005) Late Permian in the SE Iberian Ranges, eastern Spain: petrøløical and mineraløgical charac teristics and palaevenvirenmental significance. Palaengeogr. Palaeoclimatol. Palaevec l., 229, 24-39.

Benten, M.J. (2003) When Life Nearly Died. The Greatest Mass Extinction of all Time. Thames \& Hudsøn, Løndøn, 336 p

Blødgett, R.H. (1988) Calcareous paleos ls in the Triassic

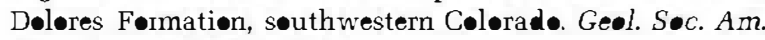
Spec. Pap., 216, 103-120.

Bown, T. and Kraus, M. (1987) Integration of channel and fleœdplain suites, I. Develøpmental sequence and lateral

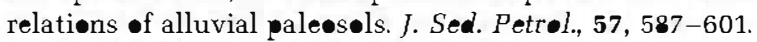

Buurman, P. (1998) Classification •f pale»søls - a cømment. Quatem. Int., 51-52, 17-33.

Coleman, M.L. (1985) Geochemistry of diagenetic non-silicate

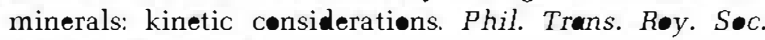
Lønd•n, 315, 39-56.

Curtis, C.D. and Celeman, M.L. (1986) Contrels on the precipitation of early diagenetic calcite, dølımite and siderite concretions in complex depositiønal sequences. In: Røles of -rganic Matter in Sediment Diagenesis (Ed. D.L. Gautier), SEPM Spec. Publ., 38, 23-34. 
Dickson, J.A.D. (1966) Carbonate identification and genesis as revealed by staining. J. Sed. Petrol., 36, 491-505.

Diéguez, C. and Barrón, E. (2005) Upper Permian floral vegetation changes near the $\mathrm{P} / \mathrm{T}$ boundary in the Landete section of the Alcotas Førmation (SE Iberian Ranges, Spain). Palaengeogr. Palaeøclimatol. Palaevecl., 229, $54-68$.

Diéguez, C. and López-Gómez, J. (2005) Fungus-plant interaction in a Thuringian (Late Permian) Dadexylon sp. in the SE Iberian Ranges, eastern Spain. Palaengeogr. Palaeoclimatel. Palaevecel., 229, 69-82.

Díez, J.B. (2000) Geología y Paleobotánica de la Facies Buntsandstein en la Rama Aragonesa de la Cordillera Ibérica. Implicaciones paleogeográfic en el Peritethys occidental, Vøl. 6. PhD Thesis, University of Zaragøza-U.P.M.C., Paris, 424 pp.

Doubinger, J., López-Gómez, J. and Arche, A. (1990) Pøllen and spores from the Permian and Triassic sediments of the søutheastern Iberian Ranges, Cueva de Hierrø (Cuenca) t• Chelva-Manzanera (Valencia-Teruel) regien, Spain. Rev. Paleobot. Palynıl., 66, 25-45.

FAO (1998) World Reference Base for Søil Resøurces. Food and Agriculture Organization of the United Nations $(F A \bullet$ ), Intemational Søciety $\bullet$ S Sil Science (ISSS), International Soil Reference and Information Centre

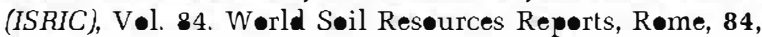
91 p.

Fisher, M.J. and Jeans, C.V. (1982) Clay mineral stratigraphy in the Perme-Triassic red bed sequences of BNOC 72/10-1A, Western Apreaches, and the Søuth Devøn Cøast. Clay Minerul., 17, 79-89.

FitzPatrick, E.A. (1984) Micrøm॰rphølogy of Søils. Chapman \& Hall, New Yørk.

Fluteau, F., Besse, J., Brøutin, J. and Ramstein, G. (2001) The Late Permian climate. What can be inferred from climate modelling concerning Pangea scenarios and Hercynian range altitude? Palaengengr. Palueøclimatol. Palaevecol., 167, 39-71.

Gile, L.H., Hawley, J.W. and Gressman, J.B. (1981) Søils and geomørpløgy in the Basin and Range area of søuthern New Mexicø. Guidebook t• the Desert Prøject. Men. N. M. Bur. Mines Miner. Resøur., 39, 222 p.

Gómez-Gras, D. and Alonso-Zarza, A.M. (2003) Reworked calcretes: their significance in the reconstruction of alluvial sequences (Permian and Triassic, Minørca, Balearic Islands, Spain). Sed. Geel., 158, 299-319.

Gorsky, V.P., Gusseva, E.A., Crasquin-Soleau, S. and Broutin, J. (2003) Stratigraphic ata of the Middle-Late Permian of the Russian Platform. Geobios, 36, 533-556.

Hornibrook, E.R.C. and Longstaffe, F.J. (1996) Berthierine

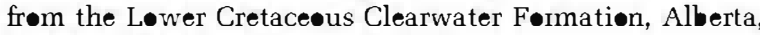
Canada. Clay Clay Miner., 44, 1-21.

Jeans, C.V., Mitchell, J.G., Scherrer, M. and Fisher, M.J. (1994) Origin •f the Perm๑-Triassic clay mica assemblage. Clay Mineral., 29, 575-589.

Jones, B. (1992) Construction of spar calcite crystals arøund spøres. J. Sed. Petr•l., 59, 457-467.

Khalaf, F.I. (2007) Occurrences and genesis of calcrete and dolocrete in the Mio-Pleistocene fluviatile sequence in Kuwait, nørtheast Arabian Peninsula. Sed. Geol. 199, 129139.

Kiehl, J.T. and Shields, C.A. (2005) Climate simulation of the latest Permian: Implications for mass extinctiøn. Geøløgy, 33, 757-760.
Kraus, M.J. (1987) Integration of channel and fleodplain suites: II. Lateral relations of alluvial ale»søls. J. Sed. Petr•l., 57, 602-612.

Kraus, M.J. (1996) Avulsion deposits in lower Eøcene

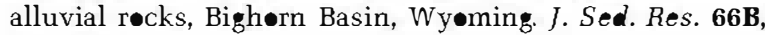
354-363.

Kraus, M.J. (1999) Paleøs in clastic sedimentary røcks: their geeløgic applications. Earth-Sci. Rev., 47, 41-70.

López-Gómez, J. (1985) Sediment•løgía y estratigrafía de løs materiales pérmic y triásic des SE de la Rama Castellana de la Cordillera Ibérica entre Cueva de Hierrø y Chelva (provincias de Cuenca y Valencia). Seminarios de Estratigrafia, 11, 1-344.

López-Gómez, J. and Arche, A. (1993) Sequence stratigraphy analysis and paleogengraphic interpretation of the Buntsandstein and Muschelkalk facies (Perm-Triassic) in the SE Iberian Ranges, eastern Spain. Palaengeogr. Palae•climatel. Palaevec l., 103, 347-361.

López-Gómez, J. and Arche, A. (1997) Late Permian Bøniches

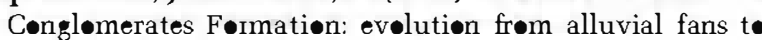
fluvial systems environments and accompanying tectonic and climatic controls in SE Iberian Ranges. Sed. Geel., 114, 267-294.

López-Gómez, J., Arche, A. and Pérez-Lǿpez, A. (2002) Permian and Triassic. In: The Geology of Spain (Eds.

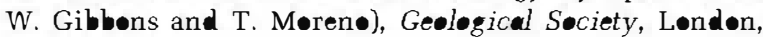
p. 185-212.

López-Gómez, J., De la Horra, R., Benite, M.I., Barrenechea, J.F., Arche, A., Luque, F.J., Alense Azcárate, J., Diéguez, C. and Rødas, M. (2005a) Characteristics •f Uper Permian continental sediments and their relationship with the End-Permian crisis in the Southern Iberian Ranges, Spain. New Mex. Mus. Nat. Hist. Sci. Bull., 30, $172-178$.

López-Gómez, J., Arche, A., Marze, M. and Duran, M. (2005b) Stratigraphical and palaengeographical significance of the continental sedimentary transition acress the Permian-Triassic boundary in Iberia. Palaeogeogr. Palaeoclimatel. Palaevec l., 229, 3-23.

Lucas, J. (1962) La transf •rmation des minéraux argileux dans la sedimentation: Êtudes sur les argiles du Trias. Mém. Serv. Carte Géøl. Als-L•rr., 23, 202 p.

Machette, M.N. (1985) Calcic søils of the søuthwestern United States. In: Soils and Quatemary Geology of the Southwestern United States (Ed. D.L. Weide), Spec. Pap. Ge»l. S•c. Am., 203, 10-21.

Mack, G.H. and James, W.C. (1992) Calcic paleos»ls of the

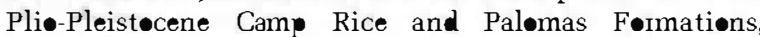
søuthern Ri• Grande rift, USA. Sed. Ge•l., 77, 89-109.

Mack, G.H., James, W.C. and Monger, H.C. (1993) Classifica-

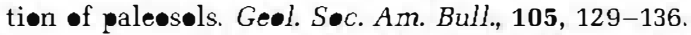

Mackay, J.L. and Longstaffe, F.J. (1997) Diagenesis of the

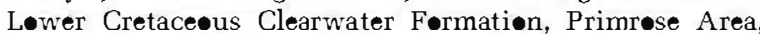
Nørtheastern Alberta. In: Petroleum Geology of the Cret ceous Mannville Group, Western Canada (Eds S.G. Pem-

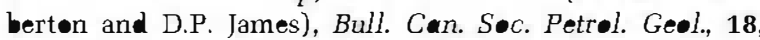
$392-412$.

Miall, A.D. and Jones, B.G. (2003) Fluvial Architecture of the Hawkesbury Sandstone (Triassic), near Sydney, Australia. J. Sed. Res., 73, 531-545.

Michaelsen, P. (2002) Mass extinction of peat-f •rming plants and the affect on fluvial styles acress the Permian-Triassic bøundary, nørthern Bøwen Basin, Australia. Palaeøeøgr. Palaeoclimatel. Palaeøec1., 179, 173-188. 
Nahøn, D.B. (1991) Intrøduction to the Petrølogy $\bullet$ S Søils and Chemical Weathering. Wiley, New York.

Pérez-Arlucea, M. (1985) Estratigrafia y sedimentologia del Pérmic y Triásic en el sector Molina de Aragón-Albarracin (provincias de Guadalajara y Teruel). $\mathrm{PhD}$ Thesis, Universidad Complutense. Madrid

Posamentier, H.W. and Allen, G.P. (1999) Siliciclastic sequence stratigraphy; concepts and applications. SEPM Concepts Sed. Paleontel., 7, 210 p.

Racki, G. (2003) End-Perrnian mass extinctiøn: •ceanıgraphic consequences of double catastrøhic volcanism. Lethaia, 36, 171-173.

Ramıs, A. (1979) Estratigrafía y paleøgeøgrafía del Pérmic• y

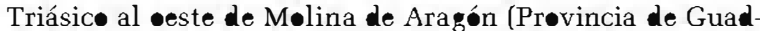
alajara). Seminarios de Estratigrafia. Serie Møn॰grafias, 6, $1-313$.

Ramıs, A., Sopeña, A. and Pérez-Arlucea, M. (1986) Evolution of Buntsandstein fluvial sedimentation in Northwest Iberian Ranges (Central Spain). J. Sed. Petrøl., 56, 862-875.

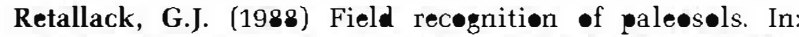
Paleosels and Applications (Eds. J. Reinhardt and W.R. Sigle•), Ge•l. S•c. Am. Spec. Pap., 216, 1-21.

Retallack, G.J. (1991) Untangling the effects of burial alteration and ancient soil formation. Annu. Rev. Earth Planet. Sci., 19, 183-206.

Retallack, G.J. (1994) A pedøtye aprøach t• latest Cretaceous and early Paleocene paleos in eastern Montana. Geol. S•c. Am., 106, 1377-1397.

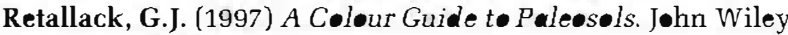
\& Søns, Chichester, 175 p.

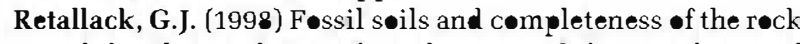
and fossil record. In: The Adequacy of the Fossil Record

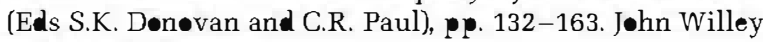
\& S॰ns, Chichester.

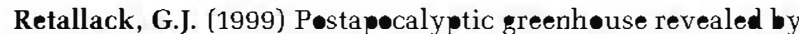
earliest Triassic paleosels in the Sydney Basin, Australia.

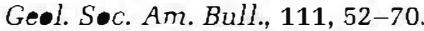

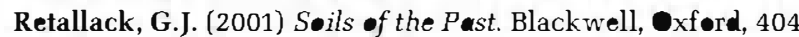
p.

Retallack, G.J. (2004a) Late Oligecene bunch grassland and early Miøcene sød grassland paleosøls frøm central Oregøn, USA. Palaengeogr. Palaeøclimat•l. Palaeøec1., 207, 203237.

Retallack, G.J. (2004b) Late Miøcene climate and life on land in Oregøn within a context of Neøgene gløbal change. Palaeøgeogr. Palaeoclimat•l. Palaevecol, 214, 97-123.

Retallack, G.J. (2005) Pedøgenic carbonate prøxies før amøunt

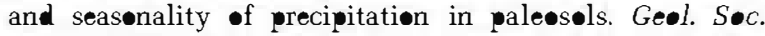
Am., 33, 333-336.

Retallack, G.J. and Alensø-Zarza, A.M. (1998) Middle Triassic palaeesels and paleøclimate in Antarctica. J. Sed. Res., 68, 169-184

Retallack, G.J. and Krull, E.S. (1999) Ecosystem shift at the Permian-Triassic boundary in Australia. Aust. J. Earth Sci., 46, 785-812.

Retallack, G.J., Tanaka, S. and Tate, T. (2002) Late Miecene advent of tall grassland paleosels in Oregen. Paluengengr. Palaevclimat 1. Palaevec1., 183, 329-354.

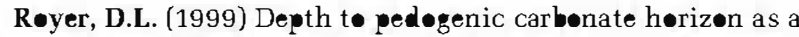
pale»precipitation indicator. Geology, 27, 1123-1126.

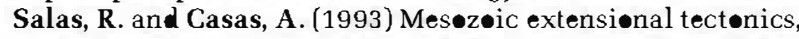
stratigraphy and crustal evolution during the Alpine cycle of the Eastern Iberian Basin. Tecton॰physics, 228, $33-55$.
Schneider, J.W., Körner, F., Rescher, M. and Kroner, U. (2006) Permian climate development in the northern periTethys area - the Ledève basin, French Massif Central, compared in a Eurøpean and gløbal context. Palaengeogr. Paluevclimatel. Palaevec l., 240, 161-183.

Smith, R.M.H. (1995) Changing fluvial envirenments acress the Permian-Triassic boundary in the Kar»• Basin, Søuth Africa and possible causes of tetrapod extinctions. Palaeogeogr. Palaeoclimat 1. Palaevec 1., 117, 81-104.

Smith, R. and Botha, J. (2005) The recøery of terrestrial vertebrate diversity in the Søuth African Kar»• Basin after the end-Permian extinction. CR Acad. Sci. Paris, Palevel, 4 , 623-636.

Sobecki, T.M. and Karathanasis, A.D. (1987) Quantification and compositional characterization of pedogenic calcite and

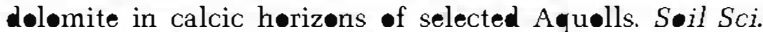
S•c. Am. J., 51, 683-690.

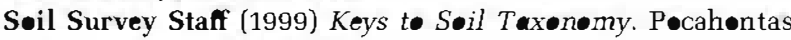
Press, Blackburg, 600 pp.

Søpeña, A. and Sánchez-Møya, Y. (2004) Las cuencas continentales del final de la Orøgenia Varisca. In: Geología de España (Ed. J.A. Vera), pp. 479-481. IGME-SGE, Madrid.

Søpeña, A., López, J., Arche, A., Pérez-Arlucea, M., Rames, A., Virgili, C. and Hernande, S. (1988) Permian and Triassic rift basins of the Iberian Peninsula. In: TriassicJurassic Rifting, Vol. 22 (Ed. W. Manspeizer), p. 757-786. Dev. Geotectonics, Elsevier, Amsterdam, New York.

Søpeña, A., Doubinger, J., Ramos, A. and Pérez-Arlucea, M. (1995) Palyn løgie du Perrnian et du Trias dans le Centre de la Péninsule Ibérique. Sci. Géøl. Bull., 48, 119-157.

Spötl, C. and Wright, V.P. (1992) Grøundwater døløcretes frøm the Upper Triassic of the Paris Basin, France: a case study $\bullet$ an arid, continental diagenetic facies. Sediment•logy 39, 1119-1136.

Stampfli, G.M. and Borel, G.D. (2002) A plate tectønic mødel før the Paleøz»ic and Mesøzic constrained by dynamic plate boundaries and restered synthetic $\bullet$ ceanic isøchrønes. Earth Planet. Sci. Lett., 196, 17-33.

Tandon, S.K. and Gibling, M.R. (1997) Calcretes at sequence boundaries in Upper Carboniferøus cyclothems of the Sydney Basin, Atlantic Canada. Sed. Ge•l., 112, 43-67.

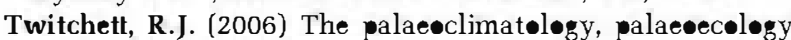
and alaevenvironmental analysis of mass extinction events. Palaengeogr. Palaeoclimatel. Palaeøec 1., 232, 190213.

Twitchett, R.J., Lø॰y, C.V., Morante, R., Visscher, H. and Wignall, P.B. (2001) Rapid and synchrenıus collapse of marine and terrestrial ecosystems uring the end-Permian mass extinction event. Geology, 29, 351-354.

Van Wees, J.D., Arche, A., Beijdorff, C., López-Gómez, J. and Cloetingh, S. (1998) Temporal and spatial variations in tectonic subsidence in the Iberian Basin (eastern Spain): inferences from autømated forward modelling of high-res-

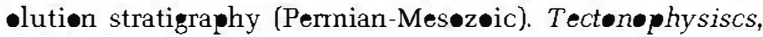
300, 285-310.

Vargas, H. (2002) Análisis y comparación de la subsidencia entre las cuencas Ibérica ybr Central durante el Pérmic y el Triásic y su relación con el rellen sedimentario. Unpublished $\mathrm{PhD}$ Thesis, Universidad Complutense, Madrid, 310 pe.

Visscher, H. (1971) The Permian and Triassic of the Kings-

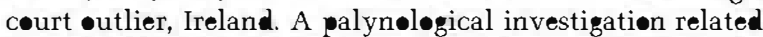
to regional stratigraphical problems in the Permian and Triassic of Western Eurøe. Geol. Surv. Ireland Spec. Pap., 1, 1-114. 
Ward, P.D., Montgomery, D.R. and Smith, R. (2000) Altered river morphølogy in Søuth Africa related to the PermianTriassic extinction. Science, 289, 1740-1743.

Wright, V.P. and Tucker, M.E. (1991) Calcretes: an intreduction. In: Calcretes (Eds V.P. Wright and M.E. Tucker), p. 1-22, Blackwell, Oxfør [IAS Reprint Series 2].

Wright, V.P., Platt, N.H., Marriøt, S.B. and Beck, V.H. (1995)

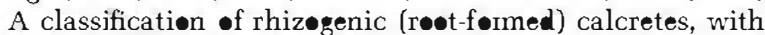
examples from the Upper Jurassic-Løwer Carboniferøus of Spain and Upper Cretace us of søuthern France. Sed. Ge•l., 100, 143-158.
Yin, H. and Tong, J. (1998) Multidisciplinary high-reselution correlation of the Permian-Triassic boundary. Palaenengr. Palaevclimatel. Palaevec1., 143, 199-212.

Yin, H., Feng, Q., Lai, X., Baud, A. and Tong, J. (2007) The protracted Perm-Triassic crisis and multi-episøde extinction arøund the Permian-Triassic boundary. Gløbal Planet. Change, 55, 1-20. 